\title{
IV Anhang
}

\section{Abkürzungsverzeichnis}

$\begin{array}{ll}{[\ldots . .]} & \text { Auslassung } \\ \dagger & \text { verstorben } \\ \text { AARS } & \text { Amis de l'Art Rupestre Saharien } \\ \text { ÄAT } & \text { Ägypten und Altes Testament } \\ \text { Abb. } & \text { Abbildung } \\ \text { AfO } & \text { Archiv für Orientforschung } \\ \text { ÄgFo } & \text { Ägyptologische Forschungen } \\ \text { ägypt. } & \text { ägyptisch } \\ \text { AH } & \text { Aegyptiaca Helvetica } \\ \text { akkad. } & \text { akkadisch } \\ \text { AOAT } & \text { Alter Orient und Altes Testament } \\ \text { AT } & \text { Altes Testament } \\ \text { BACE } & \text { Bulletin of the Australian Centre for Egyptology } \\ \text { BaM } & \text { Baghdader Mitteilungen } \\ \text { BASOR } & \text { Bulletin of the American Schools of Oriental Research } \\ \text { BAT } & \text { Biblical Archaeology Today }\end{array}$

Berl. Akad. Abh. Abhandlungen der Königlich-Preußischen Akademie der Wissenschaften zu Berlin

Berl. Mon. Ber. Bericht über die zur Bekanntmachung geeigneten Verhandlungen der Königlich-Preußischen Akademie der Wissenschaften zu Berlin

Ber Wiss Berichte zur Wissenschaftsgeschichte

Bd. Band

Bde. Bände

BJHS The British Journal for the History of Science

BSFE Bulletin de la Société Française d’Égyptologie

BZÄS Zeitschrift für Ägyptische Sprache und Altertumskunde, Beihefte

CdÉ Chronique d’Égypte

DE Discussions in Egyptology

Diss. Dissertation

frz. französisch

Gen. Genesis

GM Göttinger Miszellen. Beiträge zur ägyptologischen Diskussion

griech. griechisch

HÄB Hildesheimer Ägyptologische Beiträge

HdO Handbuch der Orientalistik

Hg. Herausgeber

HZ Historische Zeitschrift

IBAES Internet-Beiträge zur Ägyptologie und Sudanarchäologie

in Vorb. in Vorbereitung

JANER Journal of Ancient Near Eastern Religions

JAOS Journal of the American Oriental Society

Ә OpenAccess. (C) 2022 Gertzen, publiziert von De Gruyter. (cc) BY-NC-ND Dieses Werk ist lizenziert unter einer Creative Commons Namensnennung - Nicht kommerziell - Keine Bearbeitung 4.0 International Lizenz. https://doi.org/10.1515/9783110760200-005 


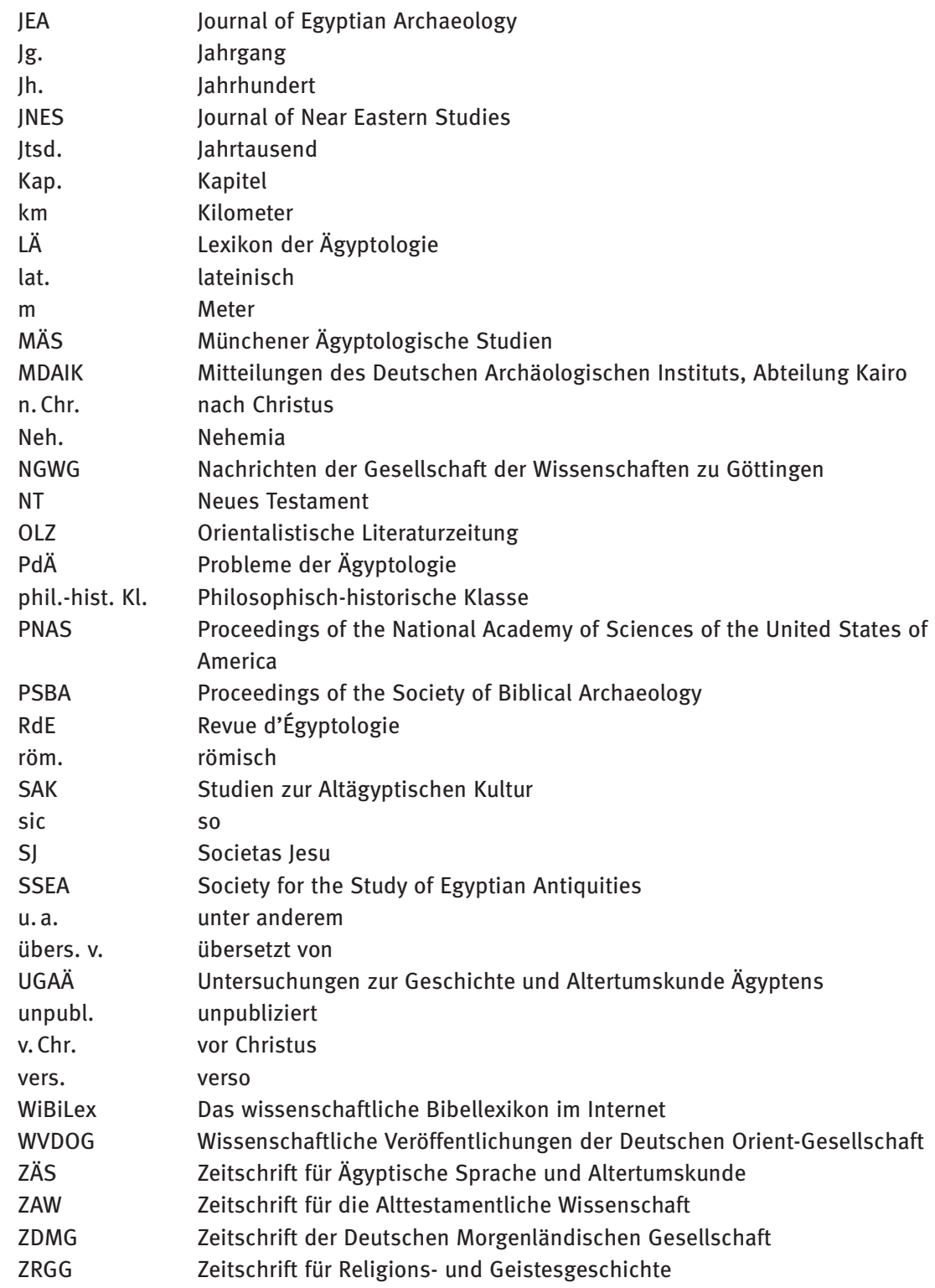




\section{Archivquellen}

Ägyptisches Museum und Universität Leipzig, Archiv (ÄMULA)

> NL Georg Steindorff, Korrespondenz, Scharff an Steindorff, 06.12.1934.

$>$ NL Georg Steindorff, Korrespondenz, Sethe an Steindorff, 27.03.1930.

$>$ NL Georg Steindorff, Korrespondenz, Sethe an Steindorff, 04.05.1930.

$>$ NL Georg Steindorff, Korrespondenz, Wolf an Steindorff, 20.11.1930.

Geheimes Staatsarchiv Preußischer Kulturbesitz [GStPK], Berlin-Dahlem

> GStPK, VI. HA, FA Bunsen, v., Karl Josias, B, Nr. 94, Bl. 383-385, Lepsius an Bunsen, 01. 01.1856.

> GStPK, VI. HA, FA Bunsen, v., Karl Josias, B, Nr. 94, Bl. 388-394, Lepsius an Bunsen, 03. 02.1856.

> GStPK, VI. HA, FA Bunsen, v., Karl Josias, B, Nr. 94, Bl. 405, Lepsius an Bunsen, 04.11. 1856.

Royal Anthropological Institute [=RAI], London, Archives \& Manuscripts

> Abbie, Andrew Arthur collection (MS 423), 1915.

\section{Bibliografie}

Abt, J., American Egyptologist. The Life of James Henry Breasted and the Creation of his Oriental Institute, Chicago 2011.

Abt, J., Seeking Permanence. James Henry Breasted and his Oriental Institute, in: van den Hout, T. (Hg.), Discovering New Pasts. The Ol at 100. Chicago 2019, 4-41.

Adkins, L. Empires of the Plain. Henry Rawlinson and the lost languages of Babylon, London 2004.

Albright, W. F., Menes and Naram-Sin, in: JEA 6, 1920, 89-98.

Albright, W. F., Professor Haupt as Scholar and Teacher, in: Adler, C. / Ember, A. (Hg.), Oriental Studies. Published in Commemoration of the Fortieth Anniversary (1883-1923) of Paul Haupt, Baltimore 1926, xxi-xxxii.

Albright, W. F., From the Stone Age to Christianity. Monotheism and the Historical Process, Baltimore 1940.

Albright, W. F., An Indirect Synchronism between Egypt and Mesopotamia, cir. 1730 B.C., in: BASOR 99, 1945, 9-18.

Albright, W. F., From the Stone Age to Christianity. Monotheism and the Historical Process ${ }^{2}$, Baltimore 1946.

Albright, W. F., Further Observations on the Chronology of the Early Second Millennium B. C., in: BASOR 127, 1952, $27-30$.

Albright, W. F., The Impact of Archaeology on Biblical Research, in: Freedman, D. N. / Greenfield, J. (Hg.), New Directions in Biblical Archaeology, New York, 1969, 1-14.

Al-Jabarti, A., Chronicle of the first seven months of the French occupation of Egypt, übers. v. Sh. Moreh, Leiden 1975.

Al-Jabarti, A., Bonaparte in Ägypten. Aus der Chronik des 'Abdarraḥmān al-Ǧabartī (1754-1829), übers. v. A. Hottinger, München 1983.

Almásy, L. E., Az ismeretlen Szahara, Budapest 1934. 
Almásy, L. E., Récentes explorations dans le Désert Libyque (1932-1936), Kairo 1936.

Almásy, L. E., Unbekannte Sahara. Mit Flugzeug und Auto in der Libyschen Wüste, Leipzig 1939.

Almathen, F. et al., Ancient and modern DNA reveal dynamics of domestication and crosscontinental dispersal of the dromedary, in: PNAS 113.24, 14.06.2016, 6707-6712.

Alter, S. G., From Babylon to Christianity: William Foxwell Albright on Myth, Folklore, and Christian Origins, in: Journal of Religious History 36.1, 2012, 1-18.

Ambridge, L., Imperialism and Racial Geography in James Henry Breasted's Ancient Times, a History of the Early World, in: Schneider, T. / Raulwing, P. (Hg.), Egyptology from the First World War to the Third Reich. Ideology, Scholarship, and Individual Biographies, Leiden 2013, $12-33$.

Anonymus, The Pyramids - Who built them ? And When?, in: Blackwood's Edinburgh Magazine $94,1863,347-364$.

Anonymus, Rezension: Massaroli, Phul e Tuklatpalasar II e Salmanasar V e Sargon, in: La Civiltà Cattolica 34, 1883, 463-475.

Anonymus, Rezension: Elliot Smith, The Evolution of the Dragon, in: Athenaeum 4652, Juni 27, 1919, $522-523$.

Anonymus, Abraham's City, in: Taunton Courier, and Western Advertiser, 05.10.1932, 3.

Archinad, A., La Chronologie sacrée basée sur les Découvertes de Champollion, Paris 1841.

Arnold, B. T., Who Were the Babylonians? (Archaeology and Biblical Studies Book 10), Leiden 2004.

Asante, M. K., Black Athena Revisited: A Review Essay, in: Research in African Literatures 29.1, 1998, 206-210.

Assmann, J., Re und Amun. Die Krise des polytheistischen Weltbilds im Ägypten der 18.-20. Dynastie, Göttingen 1983.

Assmann, J., Ägypten. Eine Sinngeschichte ${ }^{2}$, Frankfurt a. M. 2000.

Assmann, J., Das kulturelle Gedächtnis. Schrift, Erinnerung und politische Identität in den frühen Hochkulturen ${ }^{4}$, München 2002.

Assmann, J., Moses der Ägypter. Entzifferung einer Gedächtnisspur7, Frankfurt a. M. 2011.

Aufrère, S. H., Les anciens Égyptiens et leur notion de l'antiquité. Une quête archéologique et historiographique du passé, in: Méditerranées 17, 1998, 11-55.

Barr, J., Why the World was created in 4004 B.C.: Archbishop Ussher and Biblical Chronology, in: Bulletin of the John Rylands University Library of Manchester 67.2, Frühjahr 1985, $575-608$.

Barta, W., Zur Reziprozität der homosexuellen Beziehung zwischen Horus und Seth, in: GM 129, 1992, 33-38.

Baud, M., Le format de l'histoire. Annales royales et biographies des particulieres dans l’Égypte du IIII millénaire, in: Grimal, N. / Baud, M. (Hg.), Événement, récit, histoire officielle. L'écriture de l'histoire dans les monarchies antiques (Études d'Égyptologie 3), Paris 2003, 271-302.

Becker, A., Neusumerische Renaissance? Wissenschaftsgeschichtliche Untersuchung zur Philologie und Archäologie (BaM 16), Berlin 1985.

Beckerath, J. v., Gedanken zu den Daten der Sed-Feste, in: MDAK 47, 1991, 29-33.

Beckerath, J. v., Chronologie des Pharaonischen Ägypten (MÄS 46), Mainz 1997.

Beinlich, H., Kircher und Ägypten. Information aus zweiter Hand: Tito Livio Burattini, in: Ders. et al. (Hg.), Spurensuche. Wege zu Athanasius Kircher, Dettelbach 2002, 57-72. 
Beinlich, H., Zu Adolf Ermans Kritik an Athanasius Kircher, in: GM 261, 2020, 179-188.

Bernard, S., Copie d'une lettre du citoyen S.B., membre de la commission de sciences et arts d’Égypte, au citoyen Morand, membre du corps législatif, in: Gazette nationale ou le Moniteur universel, 14.02.1802, 581-582.

Beylage, P., Aufbau der königlichen Stelentexte vom Beginn der 18. Dynastie bis zur Amarnazeit (ÄAT 54), Wiesbaden 2002.

Die Bibel. Einheitsübersetzung. Altes und Neues Testament, Freiburg (Breisgau) 1991.

Bichler, R., Nachklassik und Hellenismus im Geschichtsbild der NS-Zeit. Ein Essay zur Methoden-Geschichte der Kunstarchäologie, in: Altekamp St. / Hofter, M. R. / Krumme, M. (Hg.), Posthumanistische Klassische Archäologie. Historizität und Wissenschaftlichkeit von Interessen und Methoden, München 2001, 231-249.

Biot, J.-B., Recherches sur plusieurs points de l'astronomie Égyptiennes appliquées aux monuments astronomiques trouvés en Égypte, Paris 1823.

Bonnet, H., Reallexikon der ägyptischen Religionsgeschichte³ , Berlin 2000.

Borchardt, L., Der zweite Papyrusfund von Kahun und die zeitliche Festlegung des mittleren Reiches der ägyptischen Geschichte, in: ZÄS 37, 1899, 89-103.

Borchardt, L., Quellen und Forschungen zur Zeitbestimmung der Ägyptischen Geschichte, Bd. 2: Die Mittel zur zeitlichen Feststellung von Punkten der ägyptischen Geschichte und ihre Anwendung, Kairo 1935.

Borchardt, L. / Neugebauer, P. V., Beobachtung des Frühaufgangs des Sirius in Ägypten, in: OLZ 5, 1926, 310-316.

Borchardt, L. / Neugebauer, P. V., Beobachtungen des Frühaufgangs des Sirius in Ägypten im Jahre 1926, in: OLZ 6, 1930, 441-448.

Borst, A., Der Turmbau von Babel. Geschichte der Meinungen über Ursprung und Vielfalt der Sprachen und Völker, 4 Bde., Lahnstein 2019.

Bosanquet, J. W., Assyrian and Hebrew Chronology compared, with the view of showing the extent to which the Hebrew Chronology of Ussher must be modified, in Conformity with the Assyrian Canon, in: The Journal of the Royal Asiatic Society of Great Britain and Ireland, N.S. 1.1/2, 1865, 145-180.

Bosanquet, J. W., Synchronous History of the Reigns of Tiglath-Pileser and Azariah, Shalmanezer / Jotham, Sargon / Ahaz, Sennacherib / Hezekiah, from B.C. 745 to 688, in: Transactions of the Society of Biblical Archaeology 3, 1874, 1-82.

Bouché-Leclercq, A., L'astrologie grecque, Paris 1899.

Breasted, J. H., Ancient Times, a History of the Early World. An Introduction to the Study of Ancient History and the Career of Early Man, Boston 1916.

Breasted, J. H., The Place of the Near Orient in the Career of Man and the Coming Task of the Orientalist, in: JAOS 39.3, 1919, 159-184.

Breasted, J. H., The Dawn of Conscience, New York 1933.

Bright, John, Has Archaeology found Evidence of the Flood?, in: The Biblical Archaeologist 5.4, 1942, 55-62, 72.

Brunner-Traut, E., Jean-François Champollion. Ein großer Mann, in einer großen vielbewegten Zeit (Eduard Meyer), in: Saeculum. Jahrbuch für Universalgeschichte 35.3-4, 1984, $306-325$.

Brunton, G. / Caton-Thompson, G., The Badarian Civilisation and Prehistoric Remains near Badari, London 1928. 
Buchwald, J. Z., Egyptian Stars under Paris Skies, in: Engineering \& Science 66.4, 2003, $20-31$.

Buchwald, J. Z. / Josefowicz, D. G., The Zodiac of Paris. How an Improbable Controversy over an Ancient Egyptian Artifact Provoked a Modern Debate between Religion and Science, Princeton 2010.

Buchwald, J. Z. / Josefowicz, D. G., The Riddle of the Rosetta. How an English Polymath and a French Polyglot discovered the meaning of Egyptian Hieroglyphs, Princeton 2020.

Buffon, G.-L. L., Histoire naturelle, générale et particuliére. Supplément Bd. 1, Paris 1774.

Buffon, G.-L. L., Histoire naturelle, générale et particuliére. Supplément Bd. 5, Paris 1779.

Bunsen, Ch. C. J. v., Aegyptens Stelle in der Weltgeschichte. Geschichtliche Untersuchung in Fünf Büchern, Bd. 1, Hamburg 1845.

Bunsen, Ch. C. J. v., Aegyptens Stelle in der Weltgeschichte. Geschichtliche Untersuchung in Fünf Büchern, Bd. 2, Hamburg 1844.

Bunsen, Ch. C. J. v., Aegyptens Stelle in der Weltgeschichte. Geschichtliche Untersuchung in Fünf Büchern, Bd. 3, Hamburg 1845.

Bunsen, Ch. C. J. v., Aegyptens Stelle in der Weltgeschichte. Geschichtliche Untersuchung in Fünf Büchern, Bd. 4, Gotha 1856.

Bunsen, Ch. C. J. v., Aegyptens Stelle in der Weltgeschichte. Geschichtliche Untersuchung in Fünf Büchern, Bd. 5, Gotha 1857.

Burkard, G. / Thissen, H. J., Einführung in die altägyptische Literaturgeschichte I: Altes und Mittleres Reich (Einführungen und Quellentexte zur Ägyptologie 1) ${ }^{4}$, Berlin 2012.

Cancik-Kirschbaum, E., Die Assyrer. Geschichte, Gesellschaft, Kultur, München 2003.

Cancik-Kirschbaum, E. / Kahl, J., Erste Philologien. Archäologie einer Disziplin vom Tigris bis zum Nil, Tübingen 2018.

Case, H., Rezension: Trigger, Gordon Childe, Revolutions in Archaeology, in: Antiquity 55.213, 1981, 65-66.

Cauville, S., Le Zodiaque d’Osiris. Le Zodiaque de Dendera au Musée du Louvre², Löwen 2015.

Ceram, C. W., Götter, Gräber und Gelehrte. Roman der Archäologie, Hamburg 1949.

Černý, J., Rezension: Weill, Bases, méthodes et résultats, in: AfO 5, 1928/29, 113-114.

Challis, D., The Archaeology of Race. The Eugenic Ideas of Francis Galton and Flinders Petrie, London 2013.

Champion, T., Egypt and the Diffusion of Culture, in: Jeffreys, D. (Hg.), Views of Ancient Egypt since Napoleon Bonaparte: Imperialism, Colonialism and Modern Appropriations, London 2011, 127-145.

Champollion, J.-F., Extrait d'un Memoire relatif à l'Alphabet des Hiéroglyphes phonétiques égyptiens, in: Journal des Savants 1822, 620-628.

Champollion, J.-F., Lettre à M. Dacier, ... Relative à l'Alphabet des Hiéroglyphes phonétiques: Employés par les Égyptiens pour inscrire sur leurs Monuments les Titres, les Noms et les Surnoms des Souverains Grecs et Romains, Paris 1822.

Champollion, J.-F., Précis du système hiéroglyphique des anciens Égyptiens: ou, Recherches sur les éléments premiers de cette écriture sacrée, sur leurs diverses combinaisons, et sur les rapports de ce système avec les autres méthodes graphiques Égyptiennes, Paris 1824.

Champollion, J.-F., Lettres écrites d’Egypte et de Nubie en 1828 et $1829^{2}$, Paris 1868. 
Champollion, J.-F. / Champollion Figeac, J.-J. (Hg.), Monuments de l’Égypte et de la Nubie, d'après les dessins exécutés sur les lieux sous la direction de Champollion-le-jeune, et les descriptions autographes qu'il en a rédigées, Paris 1835-1845.

Charpin, D., Les „rois archéologues“ en Mésopotamie. Entre l'authentique et le faux, in: Gaber, H. et al. (Hg.), Imitations, copies et faux dans les domaines pharaoniques et de l'Orient ancien. Actes du colloque Collège de France, Académie des Inscriptions et BellesLettres, Paris, $14-15$ janvier 2016, 176-197.

Chavals, M., Assyriology and Biblical Studies. A Century and a Half of Tension, in: Ders. / Younger, K. L. (Hg.), Mesopotamia and the Bible. Comparative Explorations (Journal for the Study of the Old Testament Supplement Series 341), New York 2002, 21-67.

Childe, V. G., The Urban Revolution, in: Town Planning Review 21.1, 1950, 3-17.

Childe, V. G., Man Makes Himself ${ }^{4}$, London 2003.

Christie, A., An Autobiography, London 1977.

Cottrell, L., The Mountains of Pharaoh. 2,000 years of Pyramid Exploration, London 1975.

Clagett, M., Ancient Egyptian Science. A Source Book, Philadelphia 1995.

Clay, A. T., The so-called Fertile Crescent and Desert Bay, in: JAOS 44, 1924, 186-201.

Clère, J. J., Bibliographie de Raymond Weill, in: RdE 8, 1951, vii-xvi.

Clutton-Brock, J., Aristotle, The Scale of Nature, and Modern Attitudes to Animals, in: Social Research 62.3, 1995, 421-440.

Collingwood, R. G., The Idea of History, überarbeitete Ausgabe, Oxford 1993.

Cook, S. A., Primitive Monotheism, in: The Journal of Theological Studies 33.129, 1931, 1-17.

Cooper, A., From the Alps to Egypt (and Back Again). Dolomieu, Scientific Voyaging, and the Construction of the Field in Eighteenth-Century Natural History, in: Smith, C. / Agar, J. (Hg.), Making Space for Science: Territorial Themes in the Shaping of Knowledge, London 1998, 39-63.

Creasman, P. P., The Potential of Dendrochronology in Egypt. Understanding Ancient Human/ Environment Interactions, in: Ikram, S. et al. (Hg.), Egyptian Bioarchaeology: Humans, Animals, and the Environment, Leiden 2014, 201-210.

Crook, P., Grafton Elliot Smith, Egyptology \& the Diffusion of Culture, Eastburn 2012.

Cryer, F. H., Chronology: Issues and Problems, in: Sasson, J. M. (Hg.), Civilizations of the Ancient Near East, Bd. 2, New York 1995, 651-664.

Cuvier, G., Discours sur les révolutions de la surface du globe et sur les changements qu'elles ont produits dans le règne animal, Paris 1826.

Cuvier, G., Fossil Bones, and Geological Catastrophes. New Translations and Interpretations of the Primary Texts, übers. v. M. J. S. Rudwick, Chicago 1997.

Czerny, E., Richard A. Bermann alias Arnold Höllriegel (1883-1939). Der Chronist auf der Suche nach der Romantik des Orients, in: Schoeps, J. H. / Gertzen, T. L. (Hg.), Grenzgänger. Jüdische Wissenschaftler, Träumer und Abenteurer zwischen Orient und Okzident, Leipzig 2020, 285-307.

Dawson, W. R. (Hg.), Sir Grafton Elliot Smith: A Biographical Record by his Colleagues, London 1938.

Daston, L., Die Kultur der wissenschaftlichen Objektivität, in: Hagner, M. (Hg.), Ansichten der Wissenschaftsgeschichte, Frankfurt a. M. 2001, 137-158.

Daumas, F., „Dendara“, in: LÄ 1, 1975, 1060-1063.

David, E., Mariette Pacha 1821-1881, Paris 1994.

Delitzsch, F., Babel und Bibel. Zweiter Vortrag, 1. bis 10. Tausend, Stuttgart 1903. 
Demandt, A., Zeit. Eine Kulturgeschichte, Berlin 2015.

Denon, D.-V., Voyage dans la Basse et la Haute Égypte, pendant les campagnes du Général Bonaparte, Paris 1802.

Deutsch, R., La nouvelle histoire. Die Geschichte eines Erfolges, in: HZ 233.1, 1981, 107-129.

Dever, W. G., What Remains of the House That Albright Built?, in: The Biblical Archaeologist 56.1, 1993: Celebrating and Examining W. F. Albright, 25-35.

Doeve, J. W., Rezension: Albright, From the Stone Age to Christianity, in: Novum Testamentum 2.1, 1957, 77-78.

Dohmen, Ch., Die Bibel und ihre Auslegung ${ }^{3}$, München 2006.

Dolomieu, D. de, Mémoire sur la constitution physique de l'Egypte. Observations sur la physique, sur l'histoire naturelle et sur les arts, Paris 1793.

Drioton, E., Rezension: Weill, Bases, méthodes et résultats, in: Journal des Savants, Mai 1928, $217-222$.

Drower, M. S., Flinders Petrie. A Life in Archaeology, London 1985.

Duclot, J., La sainte Bible vengée des attaques de l'incrédulité: et justifiée de tout reproche de contradiction avec la raison, avec les monuments de l'histoire, des sciences et des arts: avec la physique, avec la géologie, la chronologie, la géographie, l’astronomie, Bd. 1, Lyon 1855.

Dundes, A., The Flood Myth, Berkeley 1988.

Eaton-Krauss, M., Middle Kingdom Coregencies and the Turin Canon, in: JSSEA 12, 1982, $17-20$.

Ebers, G., Richard Lepsius. Ein Lebensbild, Leipzig 1885.

Eco, U., Die Suche nach der vollkommenen Sprache, München 1994.

Edel, E., Der Vertrag zwischen Ramses II. von Ägypten und Hattusili III. von Hatti (WVDOG 95), Berlin 1997.

Edgerton, W. F., The Thutmosid Succession, Chicago 1933.

Eichhorn, J. G., Urgeschichte. Erster Theil, Altdorf 1790.

Elias, N., Über die Zeit ${ }^{12}$ (Arbeiten zur Wissenssoziologie 2), Berlin 1988.

Elliot Smith, G., On the Natural Preservation of the Brain in the Ancient Egyptians, in: Journal of Anatomy and Physiology 36, 1902, 375-380.

Elliot Smith, G., Studies in the morphology of the human brain, with special reference to that of the Egyptians, in: Records of the Egyptian Government School 2, 1904, 123-172.

Elliot Smith, G., The so-called „Affenspalte“ in the human (Egyptian) brain, in: Anatomischer Anzeiger 24, 1904, 74-83.

Elliot Smith, G., The Ancient Egyptians and their Influence upon the Civilization of Europe, London 1911.

Elliot Smith, G., The Foreign Relations and Influence of the Egyptians under the Ancient Empire, in: Man. The Journal of the Royal Anthropological Institute of Great Britain and Ireland 11, 1911, 176.

Elliot Smith, G., Catalogue of the Royal Mummies in the Museum of Cairo, Kairo 1912.

Elliot Smith, G., The Migrations of Early Culture. A Study of the Significance of the Geographical Distribution of the Practice of Mummification as Evidence of the Migrations of Peoples and the Spread of certain Customs and Beliefs, London 1915.

Elliot Smith, G., The Influence of Ancient Egyptian Civilization in the East and in America, in: Bulletin of the John Rylands Library 3.1 (Januar-März) 1916, 48-77.

Elliot Smith, G., The ancient Egyptians and the origin of civilization, London 1923. 
Elliot Smith, G., The Galton Lecture, in: Eugenics Review 16.1, 1924, 1-8.

Endesfelder, E., Zur Frage der Bewässerung im Alten Ägypten, in: ZÄS 106, 1979, 37-51.

Endesfelder, E., Der Beitrag von Richard Lepsius zur Erforschung der altägyptischen

Geschichte, in: Freier, E. / Reineke, W. F. (Hg.), Karl Richard Lepsius (1810-1884). Akten der Tagung anläßlich seines 100. Todestages, 10.-12.7.1984 in Halle (Schriften zur Geschichte und Kultur des Alten Orients 20), Berlin 1988, 216-246.

E.R., Aegypten. Die neuesten Forschungen auf dem Gebiete der Aegyptologie, in: Magazin für die Literatur des Auslandes 84, 1846, 335-336.

E.R., Aegypten. Die neuesten Forschungen auf dem Gebiete der Aegyptologie (Schluß), in: Magazin für die Literatur des Auslandes 85, 1846, 340-341.

Erman, A., Aegypten und aegyptisches Leben im Altertum, Tübingen 1885.

Erman, A., Eine Revolutionszeit im Alten Ägypten, in: Internationale Monatsschrift für Wissenschaft, Kunst und Technik 6, 1912, 19-30.

Erman, A., Mein Werden und mein Wirken. Erinnerungen eines alten Berliner Gelehrten, Leipzig 1929.

Erman, A., Gedächtnisrede des Hrn. Erman auf Kurt Sethe (1934), in: Peek, W. (Hg.), Leipziger und Berliner Akademieschriften (1902-1934) (Opuscula 11), Berlin 1976, 7-12.

Ermoni, V., L'Orientalisme et la Bible, 2 Bde., Paris 1910.

Eyre, Ch. J., Is Egyptian Historical Literature „Historical“ or „Literary“?, in: Loprieno, A. (Hg.), Ancient Egyptian Literature. History and Forms (PdÄ 10), Leiden 1996, 415-433.

Färber, R. / Gautschy, R. (Hg.), Zeit in den Kulturen des Altertums. Antike Chronologie im Spiegel der Quellen, Wien 2020.

Fagan, B., The Rape of the Nile: Tomb Robbers, Tourists, and Archaeologists in Egypt, Oxford 2004.

Fallaize, E. N., Rezension: Perry, Children of the Sun und Perry, The Origin of Magic and Religion, in: Folklore 34.4 (31.12.1923), 399-402.

Feingold, M., „The Wisdom of the Egyptians“. Revisiting Jan Assmann's Reading of the Early Modern Reception of Moses, in: Aegyptiaca. Journal of the History of Reception of Ancient Egypt 4, 2019, 99-124.

Feinman, P. D., William Foxwell Albright and the Origins of Biblical Archaeology, Berrien Springs 2004.

Finegan, J., Handbook of Biblical Chronology. Principles of Time Reckoning in the Ancients World and Problems of Chronology in the Bible, 1998.

Fitzenreiter, M., Meistererzählung und Milieu, in: IBAES 20, 2018, 215-236.

Foerster, F., Christian Carl Josias Bunsen. Diplomat, Mäzen und Vordenker in Wissenschaft, Kirche und Politik (Waldeckische Forschungen 10), Bad Arolsen 2001.

Förster, F., Die „Reichseinigung“. Stand, Probleme und Perspektiven. Magisterarbeit an der Philosophischen Fakultät der Universität zu Köln, Köln 1997.

Forster, P. G., Secularization in the English Context: Some Conceptual and Empirical Problems, in: Sociological Review 20, 1972, 153-168.

Foster, B. R., The Beginnings of Assyriology in the United States, in: Holloway, St. W. (Hg.), Orientalism, Assyriology and the Bible, Sheffield 2007, 44-73.

Fourier, J.-B., Premier Mémoire sur le monumens astronomiques de l'Égypte, in: Jomard, E. F. (Hg.), Description de l'Égypte: ou recueil des observations et des recherches qui ont été faites en Égypte pendant l'expédition de l'armée française, publié par les ordres de Sa Majesté l'Empereur Napoléon le Grand 3.1.1: Texte 1: Antiquités, Paris 1809, 71-86. 
Fourier, J.-B., Recherches sur les sciences et le gouvernement de l'Égypte, in: Jomard, E. F. (Hg.), Description de l'Égypte: ou recueil des observations et des recherches qui ont été faites en Égypte pendant l'expédition de l'armée française, publié par les ordres de Sa Majesté l'Empereur Napoléon le Grand 3.1.1: Texte 1: Antiquités, Paris 1809, 803-811. Frankfort, H., Egypt and Syria in the First Intermediate Period, in: JEA 12, 1926, 80-99.

Freier, E. / Reineke, W. F. (Hg.), Karl Richard Lepsius (1810-1884). Akten der Tagung anläßlich seines 100. Todestages, 10.-12.7.1984 in Halle, Berlin 1984.

Freytag, G., Der falsche Uranios, Aus den Grenzboten 1856, Nr. 7, in: Ders., Gesammelte Werke², Bd. 16, Leipzig 1897, 379-385.

Friedell, E., Kultur ist Reichtum an Problemen. Extrakt eines Lebens, Zürich 1989.

Fritze, R. H., Egyptomania. A History of Fascination, Obsession and Fantasy, Glasgow 2016.

Gady, É., Le regard égyptologues français sur leurs collègues allemands, de Champollion à Lacau, in: Baric, D. (Hg.), Archéologies méditerranéennes, Paris 2012, 151-166.

Galton, F., Inquiries into Human Faculty and its Development, London 1883.

Gange, D., Dialogues with the Dead. Egyptology in British Culture and Religion, 1822-1922, London 2013.

Gange, D. / Ledger-Lomas, M. (Hg.), Cities of God. The Bible and Archaeology in NineteenthCentury Britain, Cambridge 2013.

Garat, D.-J., Éloge funèbre des généraux Kléber et Desaix: prononcé le $1^{\text {er }}$ vendémaire an 9, à la Place des Victoires, Paris 1800.

Gardiner, A. H., The Egyptian Origin of the Semitic Alphabet, in: JEA 3, 1916, 1-16.

Gardiner, A. H., Horus the Beḥdetite, in: JEA 30, 1944, 23-60.

Gardiner, A. H., The Royal Canon of Turin, Oxford 1959.

Gathercole, P. / Irving, T. H. / Melleuish, G. (Hg.), Childe and Australia. Archaeology, Politics and Ideas, London 1995.

Gautschy, R., Der Stern Sirius im Alten Ägypten, in: ZÄS 138, 2011, 116-131.

Gertzen, T. L. / Grötschel, M., Flinders Petrie, The Travelling Salesman Problem, and the Beginning of Mathematical Modeling in Archaeology, in: Documenta Mathematica, Sonderband: Optimization Stories, 2012, 199-210.

Gertzen, T. L., Ägyptologie im „Kulturkampf“? Der Fall Athanasius Kircher 1602-1680, in: Kemet. Zeitschrift für Ägyptenfreunde 2012.2, 52-55.

Gertzen, T. L., École de Berlin und „Goldenes Zeitalter“ (1882-1914) der Ägyptologie als Wissenschaft. Das Lehrer-Schüler-Verhältnis von Ebers, Erman und Sethe, Berlin 2013.

Gertzen, T. L., ,Brennpunkt` ZÄS. Die redaktionelle Korrespondenz ihres Gründers H. Brugsch und die Bedeutung von Fachzeitschriften für die Genese der Ägyptologie Deutschlands, in: Bickel, S. et al. (Hg.) Ägyptologen und Ägyptologien zwischen Kaiserreich und der Gründung der beiden deutschen Staaten, Berlin 2013, 63-112.

Gertzen, T. L., Die Berliner Schule der Ägyptologie im „Dritten Reich“. Begegnung mit Hermann Grapow, Berlin 2015.

Gertzen, T. L., Einführung in die Wissenschaftsgeschichte der Ägyptologie (Einführungen und Quellentexte zur Ägyptologie 10), Münster 2017.

Gertzen, T. L., Strukturgefängnis und exotischer Freiraum: Die Wissenschaftsgeschichte der Ägyptologie in der DDR, in: GM 251, 2017, 149-157.

Gertzen, T. L., Ein „Mann der philologischen Kleinarbeit“ in Theben und die Begegnung der „École de Berlin“ mit ihrem Namensgeber in Ägypten, in: Blöbaum, I. / Eaton-Krauss, M. / 
Wüthrich, A. (Hg.), Pérégrinations avec Erhart Graefe. Festschrift zu seinem 75. Geburtstag (ÄAT 87), Münster 2018, 189-202.

Gertzen, T. L., Die Vorträge des Assyriologen Friedrich Delitzsch über Babel und Bibel und die Reaktionen der deutschen Juden. Orientalismus und Antisemitismus in der Altorientalistik, in: ZRGG 71.3, 2019, 238-258.

Gertzen, T. L., „Der Studierstube der Theologen erwachsen“? Zum Verhältnis von Assyriologie, Vorderasiatischer Archäologie und Ägyptologie - einige Beobachtungen aus der Perspektive Adolf Ermans (1854-1937), in: Neumann, H. / Hiepel, L. (Hg.), Aus der Vergangenheit lernen. Altorientalistische Forschungen in Münster im Kontext der internationalen Fachgeschichte, Münster 2021, in Vorb.

Gertzen, T. L., Eine allzu lange 2. Zwischenzeit? Die ersten Bemühungen zur Erstellung einer ägyptischen Chronologie, der falsche Uranios und Richard Lepsius als Historiker, in: ZÄS 149.1, 2022, in Vorb.

Gilkey, C. W., Religion in the Post-War World, in: Journal of Bible and Religion 13.1, 1945, 3-7. Glassner, J. J., Mesopotamian Chronicles (Writings from the Ancient World 19), London 2004.

Goebs, K., A Functional Approach to Egyptian Myth and Mythemes, in: JANER 2, 2002, 27-59.

Gold, M., Ancient Egypt and the geological antiquity of man, 1847-1863, in: History of Science 57.2, 2018, 194-230.

Goodspeed, G. S., A History of the Ancient World. For High Schools and Academies, New York 1904.

Gosden, C. Anthropology and Archaeology. A changing relationship, London 1999.

Gozzoli, R. B., The Writing of History in Ancient Egypt during the First Millennium BC (ca. 1070-180 BC) Trends and Perspectives (Golden House Publications, Egyptology 5), London 2006.

Graefe, E., A propos der Pyramidenbeschreibung des Wilhelm von Boldensele aus dem Jahre 1335, in: Hornung, E. (Hg.), Zum Bild Ägyptens im Mittelalter und in der Renaissance, Freiburg (Breisgau) 1990, 9-28.

Grafton, A. T., Joseph Scaliger and Historical Chronology. The Rise and Fall of a Discipline, in: History and Theory 14.2, 1975, $156-185$.

Grapow, H., Meine Begegnung mit einigen Ägyptologen, Berlin 1973.

Greaves, J., Pyramidographia or a Description of the Pyramids in Ægypt, London 1646.

Greene, K., V. Gordon Childe and the Vocabulary of Revolutionary Change, in: Antiquity 73.279, 1999, 97-109.

Greener, L., The Discovery of Egypt, London 1966.

Griffith, J. G., The Conflict of Horus and Seth. From Egyptian and Classical Sources. A Study in Ancient Mythology, Liverpool 1960.

Guidon, N. / Delibrias, G., Carbon-14 dates point to man in the Americas 32.000 years ago, in: Nature 321, Nr. 6072, 1986, 769-771.

Guillaumont, A., Rezension: Albright, From the Stone Age to Christianity, in: Revue de l'histoire des religions 135.2-3, 1949, 231-240.

Gutschmid, A. v., Rezension: Bunsen, Aegyptens Stelle in der Weltgeschichte 4 \& 5, in: Literarisches Centralblatt für Deutschland Nr. 43, 1856, 682.

Gutschmid, A. v., Beiträge zur Geschichte des alten Orients, Leipzig 1858.

Haarmann, H., Weltgeschichte der Zahlen, München 2008. 
Hall, H. R., A Seasons' Work at Ur, Al-'Ubaid, Abu Shahrain (Eridu) and Elsewhere. Being an Unofficial Account of the British Museum Archaeological Mission to Babylonia, 1919, London 1930.

Hartleben, H., Champollion. Sein Leben und sein Werk, Bd. 1, Berlin 1906.

Hartleben, H. (Hg.), Lettres de Champollion le jeune. Lettres et journaux, écrits pendant le voyage d’Égypte, Paris 1909.

Helck, W., Herkunft und Deutung einiger Züge des frühägyptischen Königsbildes, in: Anthropos 49.5/6, 1954, 961-991.

Helck, W., Ägyptologie an deutschen Universitäten, Wiesbaden 1969.

Helck, W., s.v. „Thinitenzeit“, in: LÄ 6, Wiesbaden 1986, 486 - 493.

Helck, W., s.v. „Viehzählung“, in: LÄ 6, Wiesbaden 1986, 1038-1039.

Helck, W., Erneut das angebliche Sothis-Datum des Pap. Ebers und die Chronologie der 18. Dynastie, in: SAK 15, 1988, 149-164.

Hendrickx, S., The Relative Chronology of the Naqada Culture. Problems and Possibilities, in: Spencer, J. (Hg.), Aspects of Early Egypt, London 1993, 36-69.

Herodot, Historien. Deutsche Gesamtausgabe, übers. v. A. Horneffer, Stuttgart 1971.

Heyden, J., Biblisch Namen-Buch. Darjnn die Hebreische, Caldeische, Syrische, Griechische, un[d] Lateinische, Namen, Gottes, un[d] deß Herrn Christi, Jtem, der Menschen Völcker, Abgötter, Götzen, Königreich, Länder, Stätt, Wasser un[d] aller anderen örter eigne Wort un[d] Namen..., Frankfurt a. M. 1567.

Heyerdahl, T., The Ra-Expeditions, London 1972.

Heyerdahl, T., The Tigris Expedition. In Search of Our Beginnings, New York 1980.

Hiepel, L., Der Jesuit, Astronom und Assyriologe Franz Xaver Kugler (1862-1929) - sein Leben, Werk und Denken in der Zeit des Babel-Bibel-Streits und des Panbabylonismus, in: Gertzen, T. L. / Cancik-Kirschbaum, E. (Hg.), Der Babel-Bibel-Streit und die Wissenschaft des Judentums. Beiträge einer internationalen Konferenz vom 4. bis 6. November 2019 in Berlin (Investigatio Orientis 6), Münster 2021, 163-179.

Hincks, E., Bible History and the Rawlinson Canon, in: Athenaeum 1810, 05.07.1862, 20-22.

Hölscher, W., Libyer und Ägypter. Beiträge zur Ethnologie und Geschichte libyscher Völkerschaften nach den altägyptischen Quellen (Ägyptologische Forschungen 4), Glückstadt 1955.

Holloway, St. W., The Quest for Sargon, Pul and Tiglath-Pileser in the Nineteenth Century, in: Chavals, M. W. / Younger, K. L. (Hg.), Mesopotamia and the Bible. Comparative Explorations (Journal for the Study of the Old Testament Supplement Series 341), New York 2002, 68-87.

Hommel, F., Abriss der babylonisch-assyrischen und israelitischen Geschichte, Leipzig 1880.

Horner, L., The Anniversary Address of the President, in: The Quarterly Journal of the Geological Society of London 3, 1847, xxii-xc.

Horner, L., An account of some recent researches near Cairo, undertaken with the view of throwing light upon the geological history of the alluvial land of Egypt, Part I, in: Philosophical Transactions of the Royal Society of London 145, 1855, 105-138.

Horner, L., An account of some recent researches near Cairo, undertaken with the view of throwing light upon the geological history of the alluvial land of Egypt, Part II, in: Philosophical Transactions of the Royal Society of London 145, 1858, 53-92.

Hornung, E., Einführung in die Ägyptologie. Stand, Methoden, Aufgaben ${ }^{4}$, Darmstadt 1993. 
Hornung, E. / Krauss, R. / Warburton, D. A., Ancient Egyptian Chronology (HdO, 83.1), Leiden 2006.

Hornung, E. / Staehelin, E., Studien zum Sedfest (AH 1), Genf 1974.

Hornung, E. / Staehelin, E., Neue Studien zum Sedfest (AH 20), Basel 2006.

Huber, P. J. et al., Astronomical Dating of Babylon I and Ur III, Malibu 1982.

Huber, P. J., Astronomical Dating of Ur III and Akkad, in: AfO 46/47, 1999, 50-79.

Huber, P. J., Dating of Akkad, Ur III, and Babylon I, in: Wilhelm, G. (Hg.), Organization,

Representation and Symbols of Power in the Ancient Near East. Proceedings of the 54th Rencontre Assyriologique Internationale at Würzburg, 20 - 25th July 2008, Winona Lake 2012, $715-733$.

Hughes, J., Secrets of the Times. Myth and History in Biblical Chronology (Journal for the Study of the Old Testament, Supplement Series 66), Worcester 1990.

Irwin, W. A., Rezension: Albright, From the Stone Age to Christianity, in: The Journal of Religion 21.3, 1941, 318-319.

Iversen, E. The Myth of Egypt and its Hieroglyphs in European Tradition, Kopenhagen 1961.

Jánosi, P., Die Pyramiden. Mythos und Archäologie, München 2004.

Jeffreys D. (Hg.), The Survey of Memphis VII: The Hekekyan Papers and Other Sources for the Survey of Memphis (EES Excavation Memoir 95), London 2013.

Jideijan, N., Byblos through the Ages, Beirut 1968.

Johnston, A. K., A School Physical and Descriptive Geography², London, 1882.

Junker, H., Die Entwicklung der vorgeschichtlichen Kultur in Ägypten, in: Koppers, W. (Hg.),

Festschrift P. W. Schmidt. 76 sprachwissenschaftliche, ethnologische,

religionswissenschaftliche, prähistorische und andere Studien, Wien 1929, 865-896.

Junker, T., Geschichte der Biologie. Die Wissenschaft vom Leben, München 2004.

Jursa, M., Die Babylonier. Geschichte, Gesellschaft, Kultur, München 2004.

Kaelin, O., „Modell Ägypten“. Adoption von Innovationen in Mesopotamien des 3. Jahrtausends v. Chr. (OBO 26), Göttingen 2006.

Kaiser, W., Stand und Probleme der ägyptischen Vorgeschichtsforschung, in: ZÄS 81, 87-109. Kaplony-Heckel, U., Bunsen - der erste deutsche Herold der Ägyptologie, in: Geldbach, E.

(Hg.), Der gelehrte Diplomat. Zum Wirken Christian Carl Josias Bunsens (Beihefte der Zeitschrift für Religions- und Geistesgeschichte 21), Leiden 1980, 64-83.

Kattmann, U., Warum und mit welcher Wirkung klassifizieren Wissenschaftler Menschen?, in: Kaupen-Haas, H. / Saller, C. (Hg.), Wissenschaftlicher Rassismus. Analysen einer Kontinuität in den Human- und Naturwissenschaften, Frankfurt a. M. 1999, 65-83.

Kees, H., Horus und Seth als Götterpaar, 2 Bde., Leipzig 1923/24.

Kees, H., Kultlegende und Urgeschichte. Grundsätzliche Bemerkungen zum Horusmythos von Edfu, in: NGWG, phil.-hist. Kl., 1930, 345-362.

Kees, H., Kurt Sethe, in: NGWG, phil.-hist. Kl., Jahresbericht 1934/35, 1935, 66-74.

Kees, H., Götterglaube im Alten Ägypten, Leipzig 1941.

Kees, H., Geschichte der Ägyptologie, in: HdO 1.1, 1959, 3-17.

Keller, W., Und die Bibel hat doch recht. Forscher beweisen die historische Wahrheit, Düsseldorf 1955.

Kendall, D. G., Seriation from abundance matrices. Mathematics in the Archaeological and Historical Sciences, in: Hodson, F. R. et al. (Hg.), Mathematics in the Archaeological and Historical Sciences, Edinburgh 1971, 215- 252. 
Kendall, D. G., A Statistical Approach to Flinders Petrie's Sequence-Dating, in: Bulletin de l'Institute International de Statistique, actes de la 34e session, 40.2, 1963, 657-681.

Kendall, D. G., Some Problems and Methods in Statistical Archaeology, in: World Archaeology 1, 1969, 66-76.

Kenrick, J., Phoenicia, London 1855.

Kern, E. M:, Archaeology enters the ,atomic age': a short history of radiocarbon, 1946-1960, in: BJHS 53.2, 2020, 209-227.

Kildahl, P. A., British and American Reactions to Layard's Discoveries in Assyria (1845-1860), unpubl. Diss., University of Minnesota, 1959.

Kircher, M., Wa(h)re Archäologie. Die Medialisierung archäologischen Wissens im Spannungsfeld von Wissenschaft und Öffentlichkeit, Bielefeld 2012.

Kitchen, K. A., The Third Intermediate Period in Egypt (1100-650 BC), Warminster 1973.

Klengel, H., Geschichte des hethitischen Reiches, Leiden 1998.

Knötel, A., Die ältesten Zeiten der ägyptischen Geschichte. Nach den neuesten Entdeckungen, in: Rheinisches Museum für Philologie, Neue Folge 20, 1865, 481-503.

Köhler, E. Ch., History or Ideology? New Reflections on the Narmer Palette and the Nature of Foreign Relations in Pre- and Early Dynastic Egypt, in: Levy, T. E. / van den Brink, E. C. M. (Hg.), Egypt and the Levant, London 2002, 499-513.

Köhler, E. Ch., Vor den Pyramiden. Die ägyptische Vor- und Frühzeit, Darmstadt 2018.

Koenen, K., 1200 Jahre von Abrahams Geburt bis zum Tempelbau, in: ZAW 126.4, 2014, 494-505.

Korte, B., Archäologie in der Viktorianischen Literatur: Faszination und Schrecken der ,tiefen` Zeit, in: Middeke, M. (Hg.), Zeit und Roman. Zeiterfahrung im historischen Wandel und ästhetischer Paradigmenwechsel vom sechzehnten Jahrhundert bis zur Postmoderne, Würzburg 2002, 111-131.

Kramer, F. L., Eduard Hahn and the End of the „Three Stages of Man“, in: Geographical Review 57.1, 1976, 73-89.

Kramer, S. N., Reflections on the Mesopotamian Flood. The Cuneiform Data, New and Old, in: Expedition, Sommer, 1967, 12-18.

Kraus, F. R., Könige, die in Zelten wohnten. Betrachtungen über den Kern der assyrischen Königsliste (Mededelingen der Koningklije Nederlandse Akademie van Wetenschapen, Afd. Letterkunde, Nieuwe Reeks 28.2), Amsterdam 1965.

Krauss, R., Sothis- und Monddaten. Studien zur astronomischen und technischen Chronologie Altägyptens (HÄB 20), Hildesheim 1985.

Krauss, R., Ronald A. Wells on astronomical techniques in ancient Egyptian chronology, in: DE 57, 2003, 51-56.

Krenßheim, L., Chronologia, das ist gründtliche Jahrrechnung sampt verzeichnung der fürnemsten Geschichten, Verenderungen und Zufelle, so sich beyde in Kirchen und WeltRegimenten zugetragen haben ..., Görlitz 1577.

Krušina-Černý, L. J., Rezension: Albright, From the Stone Age to Christianity ${ }^{2}$, in: Archiv Orientální 27, 1959, 495-496.

Kuhlmann, K., s.v. „Rohrbau“, in: LÄ 5, 1984, 288-294.

Kuklick, B., Puritans in Babylon. The Ancient Near East and American Intellectual Life, 1880-1930, Princeton 1996.

Kuniholm, P. et al., Dendrochronological Dating in Egypt. Work Accomplished and Future Prospects, in: Radiocarbon 56.4, 2014, 93-102. 
Kunst, M., Intellektuelle Information - genetische Information, in: Acta Praehistorica et Archaeologica 13/14, 1982, 1-26.

Kuper, R. et al., Wadi Sura - The Cave of Beasts: A rock art site in the Gilf Kebir (SW-Egypt) (Africa Praehistorica 26), Köln 2013.

Lagier, C., Autour de la Pierre de Rosette, Brüssel 1927.

Langham, I., The Building of British Social Anthropology (Studies in the History of Modern Science 8), London 1981.

Larcher, P., Histoire d'Hérodote: traduite de grecque avec des remarques historiques et critiques, un essai sur la chronologie d'Hérodote et un table géographique ${ }^{2}$, Paris 1802.

Larsen, C. E., The Mesopotamian Delta Region: A Reconsideration of Lees and Falcon, in: JAOS 95.1, 1975, 43-57.

Larsen, M. T., The Conquest of Assyria. Excavations in an Antique Land, 1840-1860, London 1994.

Larsen, T., Austen Henry Layard's Nineveh. The Bible and Archaeology in Victorian Britain, in: Journal of Religious History 33.1, 2009, März, 66-81.

Layard, A. H., Discoveries in the Ruins of Nineveh and Babylon. With Travels in Armenia, Kurdistan and the Desert, being the result of a second expedition undertaken for the trustees of the British Museum, London 1853.

Leclant, J., Champollion, Bunsen, Lepsius, in: Freier, E. / Reineke, W. F. (Hg.), Karl Richard Lepsius (1810-1884). Akten der Tagung anläßlich seines 100. Todestages, 10.-12.7.1984 in Halle, Berlin 1984, 53-59.

Lefkowitz, M. / McLean Rogers, G. (Hg.), Black Athena revisited, Chapel Hill 1996.

Legaspi, M. C., The Death of Scripture and the Rise of Biblical Studies, Oxford 2010.

Legge, F., New Light on Sequence-Dating, in: PSBA 35, 1913, 101-113.

Lehner, M., Das Geheimnis der Pyramiden, München 1999.

Leinkauf, T. Mundus combinatus. Studien zur Struktur der barocken Universalwissenschaft am Beispiel Athanasius Kirchers SJ (1602-1680)², Berlin 2009.

Lenz, H., Universalgeschichte der Zeit ${ }^{3}$, Wiesbaden 2017.

Lenzen, H. J., Zur Flutschicht in Ur, in: BaM 3, 1964, 52-64.

Lepsius B. (Hg.), Das Haus Lepsius. Vom geistigen Aufstieg Berlins zur Reichshauptstadt, Berlin 1933.

Lepsius, C. R., Die Chronologie der Aegypter. Einleitung und Theil I: Kritik der Quellen, Berlin 1849.

Lepsius, C. R., Vorläufige Nachricht über die Expedition, ihre Ergebnisse und deren Publikation, Berlin 1849.

Lepsius, C. R / Naville, E. / Sethe, K. (Hg.), Denkmäler aus Ägypten und Äthiopien, nach den Zeichnungen der von Seiner Majestät dem Könige von Preussen Friedrich Wilhelm IV. nach diesen Ländern gesendeten und in den Jahren 1842-1845 ausgeführten wissenschaftlichen Expedition, Berlin 1849-1859.

Lepsius, C. R., Briefe aus Aegypten, Aethiopien und der Halbinsel des Sinai, geschrieben in den Jahren 1842-1845 während der auf Befehl Seiner Majestät des Königs Friedrich Wilhelm IV. von Preußen ausgeführten wissenschaftlichen Expedition, Berlin 1852.

Lepsius, C. R., Über die 12. Ägyptische Königsdynastie (Berl. Akad. Abh.), Berlin 1852.

Lepsius, C. R., Über einige Ergebnisse der ägyptischen Denkmäler für die Kenntnis der Ptolemäergeschichte (Berl. Akad. Abh.), Berlin 1852. 
Lepsius, C. R., Einige Bemerkungen zu der voranstehenden Mittheilung des Herrn Dr. Brugsch, mit Bezug auf das Verhältniß der neugefundenen Apisdaten zu einer 25-jährigen Apisperiode, in: Berl. Mon. Ber. 1853, 733-744.

Lepsius, C. R., Über den Apiskreis, in: ZDMG 7, 1853, 417-436.

Lepsius, C. R., Über den chronologischen Werth einiger astronomischer Angaben auf ägyptischen Denkmälern, in: Berl. Mon. Ber. 1854, 33-36.

Lepsius, C. R., Über einige von Hrn. Mariette brieflich übersendete Apis-Daten, nebst den Folgerungen welche sich daraus für die Chronologie der 26ten Manethonischen Dynastie und der Eroberung Ägyptens durch Kambyses ergeben, in: Berl. Mon. Ber. 1854, 217-231 und $495-498$.

Lepsius, C. R., Das allgemeine linguistische Alphabet. Grundsätze der Übertragung fremder Schriftsysteme und bisher noch ungeschriebener Sprachen in europäische Buchstaben, Berlin 1855.

Lepsius, C. R., Über einen falschen Palimpsest, in: Berl. Mon. Ber. 1856, 8.

Lepsius, C. R., Über den falschen Uranios des Simonides, in: Vossische Zeitung, Nr. 33, 08. 02.1856, 6-8.

Lepsius, C. R., Über den falschen Uranios des Simonides, in: Deutsche Allgemeine Zeitung, 10.02.1856.

Lepsius, C. R., Über den falschen Uranios des Simonides, in: Allgemeine Augsburger Zeitung, Nr. 42, 11. 02.1856, 663-664.

Lepsius, C. R., Über die manethonische Bestimmung des Umfangs der ägyptischen Geschichte, in: Berl. Mon. Ber. 1857, 420-421.

Lepsius, C. R., Das Königsbuch der alten Aegypter, Berlin 1858.

Lepsius, C. R., Über mehrere chronologische Punkte, die mit der Einführung des Julianischen und des Alexandrinischen Kalenders zusammenhängen, in: Berl. Mon. Ber. 1858, 531-551.

Lepsius, C. R., Über einige Berührungspunkte der Aegyptischen, Griechischen und Römischen Chronologie, in: Berl. Mon. Ber. 1858, 450-453.

Lepsius, C. R., Über die Entdeckung einer neuen ägyptischen Königsliste in den neu aufgedeckten Ruinen des Osiris-Tempels zu Abydos durch den Aegyptischen Reisenden Hr. Dümichen, in: Berl. Mon. Ber. 1864, 627-628.

Lepsius, C. R., Die Sethostafel von Abydos, in: ZÄS 2, 1864, 81-83.

Lepsius, C. R., Die neue Königstafel von Abydos und Herr Dümichen, in: ZÄS 4, 1866, $14-16$ und 24.

Lepsius, C. R., Rezension: Unger, G. F., Chronologie des Manetho, in: Literarisches Centralblatt für Deutschland Nr. 41, 1867, 1121-1124.

Lepsius, C. R., Über den chronologischen Werth der assyrischen Eponymen und einige Berührungspunkte mit der ägyptischen Chronologie (Berl. Akad. Abh.), Berlin 1868, 25-66.

Lepsius, C. R., Das Sothisdatum im Dekret von Kanopus, in: ZÄS 6, 1868, 36.

Lepsius, C. R., Die Kalenderreform im Dekret von Kanopus, in: ZÄS 7, 1869, 77-81.

Lepsius, C. R., Über die Annahme eines sogenannten prähistorischen Steinalters in Ägypten, in: ZÄS 8, 1870, 89-97 und 113-123.

Lequellec, J.-L. et al., Du Sahara au Nil: Peintures et gravures d'avant les pharaons, Paris 2005.

Letronne, J.-A., Recherches pour servir à l'histoire de l'Égypte pendant la domination des Grecs et des Romains, Paris 1823. 
Letronne, J.-A., Observations critiques et archéologiques sur l'objet des représentations zodiacales qui nous restent de l'antiquité, Paris 1824.

Letronne, J.-A., Sur l'origine grecque des zodiaques prétendus égyptiens, in: Revue des Deux Mondes 11, 1837, 464-491.

Levine, R., Eine Landkarte der Zeit. Wie Kulturen mit Zeit umgehen ${ }^{16}$, München 2011.

Levitin, D., John Spencer’s De Legibus Hebraeorum (1683-1685) and ,enlightened' Sacred History. A New Interpretation, in: Journal of the Warburg and Courtauld Institutes 76, 2013, 49-92.

Long, B. O., Mythic Trope in the Autobiography of William Foxwell Albright?, in: The Biblical Archaeologist 56.1, 1993: Celebrating and Examining W. F. Albright, 36-45.

Long, B. O., Planting and Reaping Albright. Politics, Ideology, and Interpreting the Bible, Philadelphia 1997.

Lucas, G., Critical Approaches to Fieldwork. Contemporary and Historical Archaeological Practice, London 2001.

Lüddeckens, E., Herodot und Ägypten, in: ZDMG 104.2, 1954, 330-346.

Luft, U., s.v. „Sothisperiode“, in: LÄ 5, 1984, 1117-1124.

Luft, U., Die chronologische Fixierung des ägyptischen mittleren Reiches nach dem Tempelarchiv von Illahun, Wien 1992.

Lyell, Ch., Principles of Geology. An Attempt to Explain the Former Changes of the Earth Surfaces, 3 Bde., London 1830.

Lyell, Ch., A Manual of Elementary Geology. The Ancient Changes of the Earth and its Inhabitants as Illustrated by Geological Monuments ${ }^{5}$, London 1855.

Macnaughton, D., A Scheme of Babylonian Chronology. From the Flood to the Fall of Niniveh, with notes thereon including notes on Egyptian and Biblical Chronology, London 1930.

Magen, B., Steinerne Palimpseste. Zur Wiederverwendung von Statuen durch Ramses II. und seine Nachfolger, Wiesbaden 2011.

Maisels, C. K., The Near East: Archaeology in the ,Cradle of Civilisation', London 1993.

Málek, J., The Original Version of the Royal Canon of Turin, in: JEA 68, 1982, 93-106.

Málek, J., La division de l'histoire d'Egypte et l'égyptologie moderne, in: BSFE 138, 1997, 6-17.

Mallowan, M., Noah's Flood reconsidered, in: Iraq 26.2, 1964, 62-82.

Mangold, S., Eine „weltbürgerliche Wissenschaft“ - die deutsche Orientalistik im 19. Jahrhundert (Pallas Athene 11), Stuttgart 2004.

Marchand, S., The end of Egyptomania. German Scholarship and the Banalization of Egypt, 1830 -1914, in: Seipel, W. (Hg.), Ägyptomanie. Europäische Ägyptenimagination von der Antike bis heute, Wien 2000, 125-133.

Mariette, A., Itinéraires de la Haute-Egypte. Comprenant une Déscription des Monuments Antiques des Rives du Nil entre le Caire et la première cataracte, Paris 1880.

Maron, G., Die römisch-katholische Kirche von 1870 bis 1970, Göttingen 1972.

Martinssen-von Falck, S. (Hg.), Die großen Pharaonen. Vom Neuen Reich bis zur Spätzeit, Wiesbaden 2018.

Massaroli, G., Phul e Tuklatpalasar II e Salmanasar V e Sargon. Questioni biblico-assire, Rom 1882.

Matthers, J. M., Excavations by the Palestine Exploration Fund at Tell el-Hesi, in: Dahlberg, B. T. / O'Connell K. G. (Hg.), Tell el-Hesi. The Site and the Expedition, London 1989, 37-67.

Meade, C. W., Road to Babylon. Development of U.S. Assyriology, Leiden 1974. 
Medina-González, I., ,Trans-Atlantic Pyramidology‘, Orientalism and Empire: Ancient Egypt and the $19^{\text {th }}$ Century Experience of Mesoamerica, in: Jeffreys, D. (Hg.), Views of Ancient Egypt since Napoleon Bonaparte: Imperialism, Colonialism and Modern Appropriations, London 2011, 107-125.

Meek, T. J., Rezension: Albright, From the Stone Age to Christianity, in: JAOS 61.1, 1941, 64-66.

Mehlitz, H., Richard Lepsius. Ägypten und die Ordnung der Wissenschaft, Berlin 2011.

Mellaart, J., Egyptian and Near Eastern chronology: A dilemma?, in: Antiquity 53, 1979, 6-18.

Melman, B., Empires of Antiquities. Modernity and the Rediscovery of the Ancient Near East, 1914-1950, Oxford 2020.

Meyer, E., Geschichte des Alterthums, Bd. 1: Geschichte des Orients bis zur Begründung des Perserreiches, Stuttgart 1884.

Meyer, E., Aegyptische Chronologie, Berlin 1904.

Meyer, E., Geschichte des Altertums ${ }^{3}$, Bd. 1, 2. Hälfte: Die ältesten Geschichtlichen Völker und Kulturen bis zum sechzehnten Jahrhundert, Stuttgart 1910.

Michalowski, P., Sumerian King List, in: Chavalas, M. W. (Hg.), Historical Sources in Translation. The Ancient Near East, Oxford 2006, 81-85.

Michell, J. F., Jews, Britons and the Lost Tribes of Israel. Eccentric lives and peculiar notions, Kempton (Illinois) 1999.

Mielke, D. P., Dendrochronologie und hethitische Archäologie - einige kritische Anmerkungen, in: Ders. et al. (Hg.), Strukturierung und Datierung in der hethitischen Archäologie (BYZAS 4), Istanbul 2006, 77-94.

Milman, H. H., The History of the Jews, from the Earliest Period Down to Modern Times, London 1865.

Mischek, U., Antisemitismus und Antijudaismus in den Werken und Arbeiten Pater Wilhelm Schmidts (1868-1954), in: Junginger, H. (Hg.), The Study of Religion under the Impact of Fascism, Leiden 2008, 467-488.

Möller, G., Aegyptisch-libysches, in: OLZ 24, 1921, 194-197.

Möller, G., Die Ägypter und ihre libyschen Nachbarn, in: ZDMG 78, 1924, 36-60.

Montet, P., Byblos et l'Egypte. Quatre Campagnes des Fouilles 1921-1924, Paris 1928.

Moore, James R., Geologists and Interpreters of Genesis in the nineteenth century, in: Lindberg, D. G. / Numbers, R. L. (Hg.), God and Nature. Historical Essays on the Encounter Between Christianity and Science, Berkeley 1986, 322-350.

Moore, M., Philosophy and Practice in Writing a History of Israel, New York 2006.

Morenz, L., Die Zeit der Regionen im Spiegel der Gebelein-Region. Kulturgeschichtliche ReKonstruktionen, Leiden 2010.

Morenz, L. D. / Sabel, D., Sinai und Alphabetschrift. Die frühesten alphabetischen Inschriften und ihr kanaanäisch-ägyptischer Entstehungshorizont im zweiten Jahrtausend v. Chr. (Studia Sinaitica 3), Berlin 2019.

Morenz, S., Traditionen um Cheops. Beiträge zur überlieferungsgeschichtlichen Methode in der Ägyptologie 1, in: ZÄS 97, 1971, 111-118.

Morkot, R. G., On the priestly origin of the Napatan kings: the adaptation, demise and resurrection of ideas in writing Nubian history, in: Reid, A. / O'Connor, D. (Hg.), Ancient Egypt in Africa, London 2003, 151-168.

Mühlenbruch, T., Von der „Urnenfelderwanderung“ zum „Seevölkersturm“ - zum Kulturwandel zwischen Mitteleuropa und Ägypten um 1200 v. Chr., in: Brandherm, D. / Nessel, B. (Hg.), 
Phasenübergänge und Umbrüche im bronzezeitlichen Europa. Beiträge zur Sitzung der Arbeitsgemeinschaft Bronzezeit auf der 80. Jahrestagung des Nordwestdeutschen Verbandes für Altertumsforschung, Bonn 2017, 215-222.

Müller, W., Das historische Museum - die Neugestaltung des Berliner Ägyptischen Museums durch Richard Lepsius, in: Freier, E. / Reineke, W. F. (Hg.), Karl Richard Lepsius (1810-1884). Akten der Tagung anläßlich seines 100. Todestages, 10.-12.7.1984 in Halle, Berlin 1984, 272- 283.

Murphy, R. T., Rezension: Albright, From the Stone Age to Christianity, in: The Thomist: A Speculative Quarterly Review 3.3, 1941, 510-517.

Murphy, R. T., Rezension: Albright, Archaeology and the Religion of Israel, in: The Thomist: A Speculative Quarterly Review 6.2, 1943, 278-281.

Mykoniati, A., Biographische Bemerkungen zu Konstantinos Simonides, in: Müller, A. E. et al. (Hg.), Die getäuschte Wissenschaft. Ein Genie betrügt Europa - Konstantinos Simonides, Göttingen 2017, 87-106.

Narr, Karl. J., Typologie und Seriation, in: Bonner Jahrbücher 178, 1978, 21-30.

Naville, E., La succession des Thoutmès d'après un mémoire récent, in: ZÄS 35, 1897, 30 - 67.

Naville, E., Un dernier mot sur la succession des Thoutmès, in: ZÄS 37, 1899, 48-55.

Neugebauer, O., A History of ancient mathematical astronomy, Berlin 1975.

Newcomb, S., The World in a Crucible. Laboratory Practice and Geological Theory at the Beginning of Geology, Boulder (Colorado) 2009.

Nissen, H.-J., Geschichte Alt-Vorderasiens (Oldenbourg Grundriss der Geschichte 25), München 1999.

Noort, E., The Stories of the Great Flood. Notes on Genesis 6:5-9:17 in its Context of the Ancient Near East, in: Martínez, F. G. / Luttikhuizen, G. P. (Hg.), Interpretations of the Flood (Themes in Biblical Narrative 1), Leiden 1998, 1-38.

Nowotny, H., Eigenzeit. Entstehung und Strukturierung eines Zeitgefühls ${ }^{4}$, Berlin 1993. O’Brien, M. J. / Lyman, R. L., Seriation, Stratigraphy and Index Fossils. The Backbone of Archaeological Dating, New York 1999.

Oels, D., Ceram - Keller - Pörtner. Die archäologischen Bestseller der fünfziger Jahre als historischer Projektionsraum, in: Hardtwig, W. / Schütz, E. (Hg.), Geschichte für Leser. Populäre Geschichtsschreibung in Deutschland im 20. Jahrhundert, Stuttgart 2005, 346-370.

Oeser, E., Cheops' Geheimnis. Die wissenschaftliche Eroberung Ägyptens, Darmstadt 2013.

Olender, M., Die Sprachen des Paradieses. Religion, Rassentheorie und Textkultur. Revidierte Neuausgabe, Berlin 2013.

Oliver, A., American Travelers on the Nile: Early U.S. Visitors to Egypt, 1774-1839, Kairo 2014. Oppert, J., s.v. „Assyrie“, in: La Grande Encyclopédie, inventaire raisonné des sciences, des lettres, et des arts par une société de savants et de gens de lettres 4, 1887, 339.

Otto, E., Der Vorwurf an Gott. Zur Entstehung der ägyptischen Auseinandersetzungsliteratur, Hildesheim 1951.

Outram, D., Georges Cuvier. Vocation, Science, and Authority in Post-revolutionary France, London 1984.

Pare, Ch., Archaeological Periods and their Purpose, in: A. Lehoërff (Hg.), Construier le temps. Histoire et méthodes des chronologies et calendriers des derniers millénaires avant notre ère en Europe occidentale. Actes du XXXe colloque international de Halma-Ipel, UMR 8164 (CNRS, Lille 3, MCC). 7-9 décembre 2006, Lille 2008, 69-84. 
Parkinson, R., ,Homosexual‘ Desire and Middle Kingdom Literature, in: JEA 81, 1995, 57-76.

Parpola, S., Back to Delitzsch and Jeremias. The Relevance of the Pan-Babylonian School to the Melammu Project, in: Panaino, A. / Piras, A. (Hg.), School of Oriental Studies and the Development of Modern Historiography. Proceedings of the Fourth Annual Symposium of the Assyrian and Babylonian Intellectual Heritage Project, held in Ravenna, October 13-17, 2001 (Melammu Symposia 4), Mailand 2004, 237-247.

Parrot, A., The Flood and Noah's Ark (Studies in Biblical Archaeology 1), New York 1955.

Pear, T. H., Some Early Relations Between English Ethnologists and Psychologists, in: The Journal of the Royal Anthropological Institute of Great Britain and Ireland 90.2 (JuliDez. 1960), 227-237.

Peet, T. E., Rezension: L. Borchardt, Die Annalen und die zeitliche Festlegung des Alten Reiches der Ägyptischen Geschichte, in: JEA 6, 1920, 149-154.

Pehal, M., Interpreting Ancient Egyptian Mythology. A Structural Analysis of the Tale of the Two Brothers and the Astarte Papyrus, Prag 2008.

Perry, W. J., The Megalithic Culture of Indonesia, London 1918.

Perry, W. J., The Children of the Sun. A Study in the Early History of Civilization, London 1923.

Petit-Maire, N., Sahara. Les grands changements climatiques naturels, Paris 2012.

Petrie, W. M. Flinders, Researches on the Great Pyramid, London 1874.

Petrie, W. M. Flinders, Inductive Metrology or the Recovery of Ancient Measures from the Monuments, London 1877.

Petrie, W. M. Flinders, Stonehenge. Plans Description and Theories, London 1880.

Petrie, W. M. Flinders, Tell el-Hesy, London 1891.

Petrie, W. M. Flinders / Quibell, J. E., Naqada and Ballas, London 1896.

Petrie, W. M. Flinders, Sequences in Prehistoric Remains, in: The Journal of the Anthropological Institute of Great Britain and Ireland 29, 1899, 295-301.

Petrie, W. M. Flinders, The Use of Diagrams, in: Man. The Journal of the Royal Anthropological Institute of Great Britain and Ireland 61, 1902, 81-85

Petrie, W. M. Flinders, Methods and Aims in Archaeology, London 1904.

Petrie, W. M. Flinders / Mace, A. C., Diospolis Parva, the cemeteries of Abadiyeh and Hu, London 1901.

Pillet, M., Raymond Weill (1874-1950), in: Revue Archéologique 42, 1953, 93-96.

Pitt-Rivers, A. H., Typological Museums. As exemplified by the Pitt Rivers Museum at Oxford and his Provincial Museum at Farnham, in: Journal of the Society of Arts 40, 1891, $115-122$.

Pockh, J. J., Güldener Denckring göttlicher Allmacht und menschlicher Thaten, welche sich begeben von Anfang der Welt durch die bißher etliche tausend verflossene Jahre, biß auf jetzt lauffende Zeit, Bd. 2, Augsburg 1740.

Poole, R. St., Horæ Agyptiacæ, or, The Chronology of Ancient Egypt, London 1851.

Poole, R. St., Egypt, Ethiopia, and the peninsula of Sinai, in: Journal of Sacred Literature and Biblical Record 6.12, Juli 1854, 314-330.

Prem, H. J., Geschichte Altamerikas, München 1989.

Price, C. / Humbert, J.-M., Introduction: An Architecture between Dream and Meaning, in: Price, C. / Humbert, J.-M. (Hg.), Imhotep Today. Egyptianizing Architecture, London 2011, 1- 24.

Quack, J. F., Karl Richard Lepsius als Historiker, in: Lepper, V. M. / Hafemann, I. (Hg.), Karl Richard Lepsius. Der Begründer der deutschen Ägyptologie, Berlin 2012, 101-119. 
Quack, J. F., Reiche, Dynastien... und auch Chroniken? Zum Bewusstsein der eigenen Vergangenheit im Alten Ägypten, in: Wiesehöfer, J. / Krüger, T. (Hg.), Periodisierung und Epochenbewusstsein im Alten Testament und in seinem Umfeld (Oriens et Occidens 20), Stuttgart 2012, 9-36.

Raffaele, F., Dynasty 0, in: Bickel, S. / Loprieno, A. (Hg.), Basel Egyptology Prize 1. Junior Research in Egyptian History, Archaeology, and Philology (AH 17), Basel 2003, 99-141.

Raige, R., Le Zodiaque nominal et primitif des anciens Égyptiens, in: Jomard, E. F. (Hg.), Description de l'Égypte: ou recueil des observations et des recherches qui ont été faites en Égypte pendant l'expédition de l'armée française, publié par les ordres de Sa Majesté l'Empereur Napoléon le Grand 3.1.1: Texte 1: Antiquités, Paris 1809, 169-180.

Raikes, R. L., The Physical Evidence for Noah's Flood, in: Iraq 28.1, 1966, 52-63.

Ramsay, Ch. et al., Radiocarbon-Based Chronology for Dynastic Egypt, in: Science 328, Nr. 5985, 2010, $1554-1557$.

Raue, D., Reise zum Ursprung der Welt. Die Ausgrabungen im Tempel von Heliopolis, Darmstadt, 2020.

Rawlinson, H. C., Assyrian Antiquities, in: Athenaeum 1243, 23.08.1851, 902-903.

Rawlinson, H. C., Babylonian Discovery: Queen Semiramis, in: Athenaeum 1381, 1854, April, 465-466.

Rawlinson, G., The Historical Evidences of the Truth of the Scripture Records Stated Anew. With Special Reference to the Doubts and Discoveries of Modern Times, in Eight Lectures, London 1860.

Rawlinson, H. C., Biblical Geography, in: Athenaeum 1799, 19.04.1862, 529-531.

Redford, D. B., Pharaonic King-Lists, Annals and Day-Books. A Contribution to the Study of the Egyptian Sense of History (SSEA Publication 4), Mississauga 1986.

Redford, D. B., The Writing of History of Ancient Egypt, in: Hawass, Z. (Hg.), Egyptology at the Dawn of the Twenty-First Century. Proceedings of the Eighth International Congress of Egyptologists, Bd. 2, Kairo 2000, 1-11.

Reingruber, A., Early Neolithic settlement patterns and exchange networks in the Aegean, in: Documenta Praehistorica 38, 2011, 291-305.

Reisenauer, E. M., The battle of the standards. Great Pyramid metrology and British Identity, 1859-1890, in: The Historian 65.4, 2003, 931-978.

Reisenauer, E. M., Anti-Jewish Philosemitism. British and Hebrew Affinity and Nineteenth Century British Antisemitism, in: British Scholar 1.1, 2008, 79-104.

Richardson, S., The First „World Event“. Senacherib at Jerusalem, in: Kalimi, I. / Richardson, S. (Hg.), Senacherib at Jerusalem. Story, History and Historiography, Leiden 2014, 433-505.

Ritter, J., Otto Neugebauer and Ancient Egypt, in: A. Jones et al. (Hrsg.), A Mathematician's Journeys. Otto Neugebauer and Modern Transformations of Ancient Science (New Studies in the History and Philosophy of Science and Technology 45), Heidelberg 2016, 127-163.

Rivers, W. H. R., The Disappearance of Useful Arts, London 1912.

Robinson, A., Cracking the Egyptian Code. The Revolutionary Life of Jean-François Champollion, London 2018.

Röllig, W., Zur Typologie und Entstehung der babylonischen und assyrischen Königslisten, in: Ders. (Hg.), lisan mithurti. Festschrift Wolfram Freiherr von Soden (AOAT 1), Tübingen 1969, 265- 277.

Rogerson, J. W., Old Testament Criticism in the Nineteenth Century. England and Germany, London 1984. 
Rohrbacher, P., ,Hamitische Wanderungen‘. Die Prähistorie Afrikas zwischen Fiktion und Realität, in: Wiedemann, F. / Hofmann, K. P. / Gehrke, H.-J. (Hg.), Vom Wandern der Völker. Migrationserzählungen in den Altertumswissenschaften, Berlin 2017, 249-282.

Rossi, P., The Dark Abyss of Time: The History of the Earth and the History of Nations from Hooke to Vico, Chicago 1987.

Rouillon-Petit, F., Campagnes des Français En Italie, En Égypte, En Hollande, En Allemagne, En Prusse, Bd. 2, Paris 1835.

Rudwick, M. J. S., The Meaning of Fossils. Episodes in the History of Palaeontology ${ }^{2}$, Chicago 1985.

Rudwick, J. S., Geologists' Time: A Brief History, in: Ders., The New Science of Geology. Studies in the Earth Sciences in the Age of Revolution, Aldershot 2004, 1-7.

Rudwick, J. S., The Shape and Meaning of Earth History, in: Ders., The New Science of Geology. Studies in the Earth Sciences in the Age of Revolution, Aldershot 2004, 296-321.

Rudwick, J. S., Bursting the Limits of Time. The Reconstruction of Geohistory in the Age of Revolution, Chicago 2005.

Rudwick, J. S., Worlds before Adam. The Reconstruction of Geohistory in the Age of Reform, Chicago 2008.

Running, L. G. / Freedman, D. N., William Foxwell Albright. A twentieth century genius, New York 1975.

Ruppel, H.-R. et al., Universeller Geist und guter Europäer. Chr. Carl Josias von Bunsen. Beiträge zu Leben und Werk des „gelehrten Diplomaten“, Korbach 1991.

Sachs, A. / Hunger, H., Astronomical Diaries and Related Texts from Babylon, 3 Bde., Wien 1988-1996.

Säve-Söderbergh, T., The Hyksos Rule in Egypt, in: JEA 37, 1951, 53-71.

Saint-Martin, J., Notice sur Le Zodiaque de Denderah, Lue á l'Académie royale des Inscriptions et Belles-Lettres, dans la séance du 8 février 1822, Paris 1822.

Sass, B., The Genesis of the Alphabet and its Development in the Second Millennium B.C. (ÄAT 13), Wiesbaden 1988.

Sasson, J. M., Albright as an Orientalist, in: The Biblical Archaeologist 56.1, 1993: Celebrating and Examining W. F. Albright, 3-7.

Saulnier, S.-L., Notice sur le voyage de M. Lelorrain en Egypte: et observations sur le Zodiaque de Denderah, Paris 1822.

Sayce, H. A., s.v. „Babylonia“, in: The Encyclopaedia Britannica or Dictionary of Arts, Sciences, and General Literature ${ }^{9}$, Bd. 3, New York 1886, $182-194$.

Sayce, H. A., The „Higher Criticism“ and the Verdict of the Monuments ${ }^{4}$, London 1894.

Schaffer, S., Metrology, Metrication, and Victorian Values, in: Lightman, B. (Hg.), Victorian Science in Context, Chicago 1997, 438-474.

Schaper, R., Die Odyssee des Fälschers, Die abenteuerliche Geschichte des Konstantin Simonides, der Europa zum Narren hielt und nebenbei die Antike erfand, München 2014.

Scharff, A., Kurt Sethe, in: Jahrbuch der Bayerischen Akademie der Wissenschaften, Jg. 1934/ $35,32-39$.

Scharff, A., Kurt Sethe, in: Egyptian Religion 2.3, 1935, 116-118.

Scharff, A., Die Ausbreitung des Osiriskultes in der Frühzeit und während des Alten Reiches (Sitzungsberichte der Bayerischen Akademie der Wissenschaften. Philosophischhistorische Klasse, Jg. 1947.4), München 1948. 
Schenkel, W., Einführung der künstlichen Felderbewässerung im Alten Ägypten, in: GM 11, 1974, 41- 46.

Schenkel, W., Die Bewässerungsrevolution im Alten Ägypten, Mainz 1978.

Schenkel, W., Erkundungen zur Reihenfolge der Zeichen im ägyptologischen Transkriptionsalphabet, in: CdÉ 125, 1988, 5-35.

Schenkel, W., Bruch und Aufbruch. Adolf Erman und die Geschichte der Ägyptologie, in: Schipper, B. (Hg.), Ägyptologie als Wissenschaft. Adolf Erman (1854-1937) in seiner Zeit, Berlin 2006, 224-247.

Schildt, A., Zwischen Abendland und Amerika. Studien zur westdeutschen Ideenlandschaft der 50er Jahre, Berlin 1999.

Schlote, K.-H. (Hg.), Chronologie der Naturwissenschaften. Der Weg der Mathematik und der Naturwissenschaften von den Anfängen in das 21. Jahrhundert, Frankfurt a. M. 2002.

Schmidt, W., Der Ursprung der Gottesidee. Eine historisch-kritische und positive Studie, 12 Bde., Münster 1912-1955.

Schneider, T., Die Periodisierung der ägyptischen Geschichte. Probleme und Perspektiven für die ägyptologische Historiographie, in: Hofmann, T. / Sturm, A. (Hg.), Menschen-Bilder / Bilder-Menschen. Kunst und Kultur im Alten Ägypten, Norderstedt 2003, 241-256.

Schneider, T., Periodizing Egyptian History: Manetho, Convention, and Beyond, in: Adam, K.-P. (Hg.), Historiographie in der Antike (Beihefte zur Zeitschrift für alttestamentliche Wissenschaft 373), Berlin 2008, 181-195.

Schneiders, W., Das Zeitalter der Aufklärung ${ }^{5}$, München 2014.

Schott, S., Spuren der Mythenbildung, in: ZÄS 78, 1942, 1-27.

Schrader, E., Keilinschriften und das Alte Testament, Gießen 1872.

Schröder, H.-Chr., Englische Geschichte ${ }^{7}$, München 2017.

Schroeer, J. F., Imperium Babylonis et Nini ex monimentis antiquis, Frankfurt a. M. 1726.

Scott, J. C., Against the Grain. A Deep History of the Earliest States, New Haven 2018.

Selz, G. J., Sumerer und Akkader. Geschichte, Gesellschaft, Kultur, München 2005.

Sethe, K., Die Thronwirren unter den Nachfolgern Königs Thutmosis' I. Ihr Verlauf und ihre Bedeutung (UGÄ̈ 1), Leipzig 1896.

Sethe, K., Altes und Neues zur Geschichte der Thronstreitigkeiten unter den Nachfolgern Thutmosis I., in: ZÄS 36, 1898, 24-81.

Sethe, K., Beiträge zur ältesten Geschichte Ägyptens (Untersuchungen zur Geschichte und Altertumskunde Ägyptens 3), Leipzig 1905.

Sethe, K., Die Namen von Ober- und Unterägypten und die Bezeichnungen von Nord und Süd, in: ZÄS 44, 1907, 1-30.

Sethe, K., Zur Erklärung einiger Denkmäler aus der Frühzeit der ägyptischen Kultur, in: ZÄS 52, 1915, 56.

Sethe, K., Die Ägyptologie. Zweck, Inhalt und Bedeutung dieser Wissenschaft und Deutschlands Anteil an ihrer Entwicklung (Der Alte Orient 23), Leipzig 1921.

Sethe, K., Die Sprüche für das Kennen der Seelen der heiligen Orte (Totb. Kap. 107-109. 111-116.). Göttinger Totenbuchstudien von 1919, in: ZÄS 59, 1924, 73-99.

Sethe, K., Amun und die acht Urgötter von Hermopolis. Eine Untersuchung über Ursprung und Wesen des aegyptischen Götterkönigs, Berlin 1929.

Sethe, K., Urgeschichte und älteste Religion der Ägypter (Abhandlungen für die Kunde des Morgenlandes 18.4), Leipzig 1930. 
Sethe, K., Das Hatschepsut-Problem noch einmal untersucht, in: Berl. Akad. Abh., Phil.-hist. Kl., 1932.

Shalev, Z., Measurer of All Things: John Greaves (1602-1652), the Great Pyramid, and Early Modern Metrology, in: Journal of the History of Ideas 63.4, 2002, 555-575.

Shephard, B., Headhunters. The Search for a Science of the Mind, London 2015.

Silberman, N. A., Petrie's Head. Eugenics and Near Eastern Archaeology, in: Kehoue, A. B. / Emmerichs, M. B. (Hg.), Assembling the Past. Studies in the Professionalization of Archaeology, Albuquerque 1999, 69-79.

Simiand, F., Méthode historique et science sociale, in: Annales 15.1, 1960, 83-119.

Smith, G., The annals of Tiglath Pileser II, in: ZÄS 7, 1869, 9-17.

Smith, G., The Assyrian Eponym Canon, London 1875.

Smith, W., s.v. „Gennes'aret, Land of“, in: A Concise Dictionary of the Bible for the Use of Families and Students, London 1865, 287.

Smyth, Ch. P., On the reputed Metrological System of the Great Pyramid. A paper read before the Royal Society of Edinburgh, $21^{\text {st }}$ March 1864, in: Transactions of the Royal Society of Edinburgh, 1864, 667-699.

Smyth, Ch. P., Life and Work at the Great Pyramid, 3 Bde., Edinburgh 1867.

Smyth, Ch. P., Our Inheritance in the Great Pyramid, Edinburgh 1874.

Soden, W. v., s.v. „Assyrien“, in: Religion in Geschichte und Gegenwart $650-655$.

Soden, W. v., Einführung in die Altorientalistik ${ }^{2}$, Stuttgart 1992.

Sommer, M., Die Phönizier. Geschichte und Kultur, München 2008.

Sowada, K., The Politics of Error. Flinders Petrie at Diospolis Parva, in: BACE 7, 1996, 89-96.

Stadelmann, R., Die ägyptischen Pyramiden. Vom Ziegelbau zum Weltwunder ${ }^{3}$, Mainz 1997.

Stanley, St. M., Historische Geologie², Berlin 2001.

Steger, F. (Hg.), Ergänzungs-Conversationslexikon 11 = N.F. 4, Leipzig 1856, s.v. Konstantin Simonides, 737-749.

Steindorff, G., Die Blütezeit des Pharaonenreiches, Leipzig 1926.

Steindorff, G., Kurt Sethe, in: ZÄS 70, 1934, 132-134.

Stock, H., Studien zur Geschichte und Archäologie der 13. bis 17. Dynastie Ägyptens, unter besonderer Berücksichtigung der Skarabäen dieser Zwischenzeit (ÄgFo 12), Glückstadt 1942.

Stocking, G. W., After Tylor. British Social Anthropology 1888-1951, London 1999.

Strasser, G. F., La Contribution d'Athanase Kircher à la tradition humaniste hiéroglyphique, in: XVIle Siècle 158, 1988, 79-92.

Strasser, G. F., Lingua realis, lingua universalis und lingua cryptologica. Analogienbildung bei den Universalsprachen des 16. und 17. Jahrhunderts, in: Berichte zur Wissenschaftsgeschichte 12, 1989, $203-217$.

Strasser, G. F., Das Sprachdenken Athanasius Kirchers, in: Coudret, A. P. (Hg.) Die Sprache Adams (Wolfenbütteler Forschungen 84), Wiesbaden 1999, 151-169.

Strobel, A., Der spätbronzezeitliche Seevölkersturm. Ein Forschungsüberblick mit Folgerungen zur biblischen Exodusthematik (Beihefte für die Zeitschrift für die alttestamentliche Wissenschaft 145), Berlin 1976.

Tadmor, H., Niniveh, Calah and Israel. On Assyriology and the Origins of Biblical Archaeology, in: BAT. Proceedings of the International Congress of Biblical Archaeology 1984, Jerusalem 1985, 260-267. 
Taylor, J., The Great Pyramid. Why was it built and who built it, London 1859.

Testa, G. D., Dissertazione sopra due Zodiaci novellamente scoperti nell'Egitto in una adunanza straordinaria dell'Accademia di Religione Cattolica, Rom 1802.

Thesiger, W., The Marsh Arabs, London 1964.

Thums, B., Ausgraben, Bergen, Deuten: Literatur und Archäologie im 19. Jahrhundert, in: Samida, S. (Hg.), Inszenierte Wissenschaft: Zur Popularisierung von Wissen im 19. Jahrhundert, Bielefeld 2011, 43-59.

Thomasson, F., The Life of J. D. Åkerblad: Egyptian Decipherment and Orientalism in Revolutionary Times (Brill's Studies in Intellectual History 213), Leiden 2013.

Thompson, M.W., General Pitt-Rivers. Evolution in Archaeology in the Nineteenth Century, Bradford-on-Avon 1977.

Thompson, R. C., Rezension von: Woolley, Recent Discoveries and Hebrew Origins, in: The Antiquaries Journal 16.4, 1936, 476-480.

Tischendorf, K. v., Noch ein Wort zur Uranios-Frage, in: Lykurgos, A. (Hg.), Enthüllungen über den Simonides-Dindorffschen Uranios, Leipzig 1856, 73-76.

Townend, B. R., The Story of the Tooth-Worm, in: Bulletin of the History of Medicine 15.1, 1944, 37-58.

Trigger, B., Gordon Childe, Revolutions in Archaeology, London 1980.

Trigger, B., A History of Archaeological Thought ${ }^{12}$, Cambridge 2004.

Tringham, R., V. Gordon Childe 25 years after: His relevance for the archaeology of the eighties, in: Journal of Field Archaeology 10.1, 1983, 85-100.

Trümpener, H.-J., Die Existenzbedingungen einer Zwergwissenschaft. Eine Darstellung des Zusammenhanges von wissenschaftlichem Wandel und der Institutionalisierung einer Disziplin am Beispiel der Ägyptologie, Bielefeld 1981.

Ucko, P. J., The Biography of a Collection. The Flinders Petrie Palestinian Collection and the Role of University Museums, in: Museum Management and Curatorship 17.4, 1998, 351-399.

Ussher, J., Annales Veteris et Novi Testamenti, a prima mundi origine deducti. Una cum rerum Asiaticarum et Aegyptiacarum chronico, a temporis historici principio usque ad extremum templi et reipublicae Judaicae excidium producto, London 1650.

Van Binsbergen, W., Black Athena. Ten Years Later. Towards a constructive reassessment, in: Ders. (Hg.), Black Athena comes of age. Towards a constructive reassessment, Münster 2011, 11-64.

Van Buren, E. D., Archaeologists in Antiquity, in: Folklore 36.1, 1925, 69-81.

Van de Mieroop, M., The Mesopotamians and their Past, in: Wiesehöfer, J. / Krüger, T. (Hg.), Periodisierung und Epochenbewusstsein im Alten Testament und in seinem Umfeld (Oriens et Occidens 20), Stuttgart 2012, 37-56.

Van den Brink, E. C. M. (Hg.), The Nile Delta in Transition: $4^{\text {th }}-3^{\text {rd }}$ Millennium B.C., Tel Aviv 1992.

Van der Pflicht, J. / Bruins, H. J., Radiocarbon dating in Near-Eastern contexts. Confusion and quality control, in: Radiocarbon 43.3, 2002, 1155-1166.

Vandier, J., La Religion Égyptienne (Mana. Introduction à l'histoire des Religions), Paris 1944. Vandier, J., Raymond Weill (1874-1950), in: RdE 8, 1951, i-vi.

Veenhof, K. R., Geschichte des Alten Orients bis zur Zeit Alexanders des Großen (Grundrisse zum Alten Testament, Ergänzungsreihe 11), Göttingen 2001. 
Veit, U., Gustaf Kossina und V. Gordon Childe: Ansätze zu einer theoretischen Grundlegung der Vorgeschichte in: Saeculum 45.3/4, 1984, 326-363.

Virenque, H., Hermine Hartleben. Biographe de J.-Fr. Champollion, in: Senouy 14, 2015, 37-42.

Vogtherr, T., Zeitrechnung. Von den Sumerern bis zur Smartwatch³, München 2012.

Voss, S., Ludwig Borchardts Recherche zur Herkunft des pEbers, in: MDAIK 65, 2009, $373-376$.

Voss, S., La représentation égyptologique allemande en Égypte et sa perception par les égyptologues français, du XIX ${ }^{\mathrm{e}}$ au milieu du XX $X^{\mathrm{e}}$ siècle, in: Baric, D. (Hg.), Archéologies méditerranéennes, Paris 2012, 167-188.

Voss, S., Wissenshintergründe ... - die Ägyptologie als ,völkische“ Wissenschaft entlang des Nachlasses Georg Steindorffs von der Weimarer Republik über die NS- bis zur Nachkriegszeit, in: Dies. / Raue, D. (Hg.), Georg Steindorff und die deutsche Ägyptologie im 20. Jahrhundert (BZÄS 5), Berlin 2016, 105-332.

Voss, S., Die Geschichte der Abteilung Kairo des DAI im Spannungsfeld deutscher politischer Interessen, Bd. 2: 1929-1966 (Menschen - Kulturen - Traditionen 8.2), Rahden (Westf.) 2017.

Vyse, R. W. H., Operations carried on at the Pyramids of Gizeh in 1837, with an Account of a Voyage into Upper Egypt, and an Appendix, Bd. 1, London 1840.

Waetzoldt, H., Zu den Strandverschiebungen am Persischen Golf und den Bezeichnungen der Hors, in: Schäfer, J. / Simon, W. (Hg.), Strandverschiebungen in ihrer Bedeutung für Geowissenschaften und Archäologie, Heidelberg 1981, 159-184.

Weichenhan, M., Der Panbabylonismus. Die Faszination des himmlischen Buches im Zeitalter der Zivilisation, Berlin 2016.

Weill, R., La fin du Moyen Empire Égyptien. Étude sur les monuments et l'histoire de la période comprise entre la 12e et la 18e dynastie, Paris 1918.

Weill, R., Bases, méthodes et résultats de la Chronologie Égyptienne, 2 Bde., Paris 1926-1928.

Weill, R., Les Nouvelle Propositions de Reconstruction Historique et Chronologie du Moyen Empire, in: RdE 7, 1950, 89-105.

Weill, R., Douzième Dynastie, Royauté de Haute-Égypte et Domination Hyksos dans le nord, Paris 1953.

Wengrow, D., The archaeology of early Egypt. Social transformations in North-East Africa, 10,000 to 2650 BC, Cambridge 2006.

Westendorf, W., „Auf jemandes Wasser sein“ = „von ihm abhängig sein“, in: GM 11, 1974, $47-48$.

Westendorf, W., Kurt Sethe, in: Arndt, K. et al. (Hg.), Göttinger Gelehrte. Die Akademie der Wissenschaften zu Göttingen in Bildnissen und Würdigungen 1751-2001, Göttingen 2001, $344-345$.

Wildung, D., Die Rolle ägyptischer Könige im Bewußtsein ihrer Nachwelt (MÄS 17), Bd. 1, Berlin 1969.

Wilkinson, T. A. H., Royal Annals of Ancient Egypt. The Palermo Stone and its Associated Fragments, London 2000.

Wilson, J., The Relation between Ideology and Organization in a Small Religious Group: The British Israelites, in: Review of Religious Research 10.1, 1968, 51-60. 
Wilson, J. A., Rezension: Weill, Douzième Dynastie, royauté de Haute-Égypte, in: JNES 14.2, 1955, 131-133.

Winer, G. B., Biblisches Realwörterbuch zum Handgebrauch für Studirende, Candidaten, Gymnasiallehrer und Prediger, 2 Bde., Leipzig 1820.

Winstone, H. V. F., Woolley of Ur. The Life of Sir Leonard Woolley, London 1990.

Winter, I. J., Babylonian Archaeologists of the(ir) Mesopotamian Past, in: Matthiae, P. et al. (Hg.), Proceedings of the First International Congress of the Archaeology of the Ancient Near East. Rome, May $18^{\text {th }}-23^{\text {rd }} 1998$, Rom 2000, 1787-1800.

Wirth, A., Männer, Völker und Zeiten, Berlin 1912.

Witzel, M., Das Alte Indien², München 2010.

Wittfogel, K. A., Oriental Despotism: A Comparative Study of Total Power, New Haven 1957.

Wiwjorra, I., „Ex oriente lux“ - „Ex septentrione lux“. Über den Widerstreit zweier Identitätsmythen, in: Leube, A. / Hegewisch, M. (Hg.), Prähistorie und Nationalsozialismus. Die mittel- und osteuropäische Ur- und Frühgeschichtsforschung in den Jahren 1933-1945 (Studien zur Wissenschafts- und Universitätsgeschichte 2), Heidelberg 2002, 73-106.

Woolley, L., Excavations at Ur, 1928-9, in: The Antiquaries Journal 9, Oktober 1929, Nr. 4, $322-330$.

Woolley, L., Ur of the Chaldees. A Record of Seven Years of Excavation, London 1929.

Woolley, L., The Excavations at Ur and the Hebrew Records, London 1929.

Woolley, L., Ur und die Sintflut. Sieben Jahre Ausgrabungen in Chaldäa, der Heimat Abrahams, Leipzig 1930.

Woolley, L., Excavations at Ur 1929-30, in: The Antiquaries Journal 10.4, 1930, 315-343.

Woolley, L., Abraham. Recent Discoveries and Hebrew Origins, London 1936.

Woolley, L., The Flood, in: The South African Archaeological Bulletin 8.30, 1953, 52 - 54.

Woolley L., Excavations at Ur. A Record of Twelve Years' Work, New York 1954.

Woolley, L., Ur Excavations 4: The early periods, Philadelphia 1955.

Wortham, J. D., British Egyptology 1549-1906, Newton Abbot 1971.

Ydit, M., Kurze Judentumkunde für Schule und Selbststudium, Berlin 2018.

Younger, K. L., Recent Study on Sargon II, King of Assyria. Implications for Biblical Studies, in: Chavals, M. W. / Younger, K. L. (Hg.), Mesopotamia and the Bible. Comparative Explorations (Journal for the Study of the Old Testament Supplement Series 341), New York 2002, 288-329.

Zboray, A., Some results of recent expeditions to the Gilf Kebir \& Jebel Uweinat, in: Cahiers de l'AARS 8, 2003, 97-104.

Zettler, R. L. / Horne, L. (Hg.), Treasures from the Royal Tombs of Ur, Philadelphia 1998.

Zimon, H., Wilhelm Schmidt's Theory of Primitive Monotheism and its Critique within the Vienna School of Ethnology, in: Anthropos 81.1-3, 1986, 243-260.

Zink MacHaffie, B., Monument Facts and Higher Critical Fancies. Archaeology and the Popularization of Old Testament Criticism in Nineteenth Century Britain, in: Church History 50.3, 1981, 316-328. 


\section{Internetressourcen}

Der letzte Zugriff auf die hier aufgeführten und in den Fussnoten zitierten Web-Seiten erfolgte, soweit nicht anders angegeben, am 10. August 2021.

Anonymus, Exhibition: 47 Leicester Square, Zodiac of Dendera, London 1825: http://iapsop. com/ssoc/1825_anonymous_exhibition_of_the_zodiac_of_dendera.pdf.

Aufgebauer, P., Die astronomischen Grundlagen des französischen Revolutionskalenders eine wissenschaftsgeschichtliche Studie: http://webdoc.sub.gwdg.de/edoc/p/fundus/4/ aufgebauer.pdf.

Berg, L., Auf den Spuren der ersten Amerikaner. Ein Weltkulturerbe im Nordosten Brasiliens untergräbt die klassische Theorie zur Besiedlung des Kontinents, in: Frankfurter Allgemeine Zeitung, 07.06.2018: https://www.faz.net/aktuell/wissen/archaeologie-alter tum/weltkulturerbe-auf-den-spuren-der-ersten-amerikaner-15624830.html.

Berner, Ch., „Chronologie, biblische (AT)“, in: WiBiLex. Das wissenschaftliche Bibellexikon im Internet, 2016: http://www.bibelwissenschaft.de/stichwort/16053.

British Museum and the Penn Museum, Ur Online, Charles Leonard Woolley: http://www.ur-on line.org/personorg/10.

Challenging Time(s) - A New Approach to Written Sources for Ancient Egyptian Chronology: https://www.oeaw.ac.at/oeai/forschung/altertumswissenschaften/antike-rechtsgeschich te-und-papyrologie/challenging-times.

CHRONOS. Soziale Zeit in den Kulturen des Altertums: https://www.chronos.humanities.uva.nl.

Curtis, C. et al., The Sacred Ibis debate: The first test of evolution, in: PLOS Biology 16.10, 2018: https://journals.plos.org/plosbiology/article?id=10.1371/journal.pbio. 2005558.

Dahm, Ph., 15 historische Fakten, die dir ein völlig neues Zeitgefühl geben: https://www.wat son.ch/wissen/panorama/241564166-15-historische-fakten-die-dir-ein-voellig-neues-zeit gefuehl-geben.

DFG-Magazin, Serra da Capivara - älteste Siedlungsspuren in Amerika? Fotoausstellung zu brasilianischem Weltkulturerbe, 06.04.2017: https://www.dfg.de/dfg_magazin/veranstal tungen/ausstellungen/serra_di_capivara/index.html.

Einstein Center CHRONOI: https://www.ec-chronoi.de.

Flavius Josephus, Apologie für das Alter des Judentums, Vorläufige Übersetzung des Institutum Judaicum Delitzschianum, Münster 2003: https://www.uni-muenster.de/EvTheol/ijd/for schen/contra-apionem.html.

Gestermann, L., s.v. „Pyramidentexte“, in: WiBiLex. Das wissenschaftliche Bibellexikon im Internet, 2006: https://www.bibelwissenschaft.de/stichwort/31660.

Glain, St. J., Effort to unwrap lineage of mummies hits wall, aus: The Wall Street Journal, 03. 05. 2001, online: https://www.deseret.com/2001/5/3/19584238/effort-to-unwrap-line age-of-mummies-hits-wall.

Gundacker, R., „Manetho“, in: WiBiLex. Das wissenschaftliche Bibellexikon im Internet, 2018: https://www.bibelwissenschaft.de/stichwort/25466.

Höflmayer, F., Radiocarbon Dating and Egyptian Chronology - From the „Curve of Knowns“ to Bayesian Modeling, in: Oxford Handbooks Online. Scholarly Research Reviews, 2016: https://www.oxfordhandbooks.com/view/10.1093/oxfordhb/9780199935413.001.0001/ox fordhb-9780199935413-e-64. 
Holloway, St. W., Biblical Assyria and Other Anxieties in the British Empire, in: Journal of Religion \& Society 3, 2001: http://moses.creighton.edu/jrs/2001/2001-12.pdf.

Howell, C. / Kaufmann Kohler, s.v. „Jubilees, book of“, in: Jewish Encyclopedia, 1906, S. 301: http://www.jewishencyclopedia.com/articles/8944-jubilees-book-of.

Kuper, R. / Kröpelin, St., Climate-Controlled Holocene Occupation in the Sahara: Motor of Africa's Evolution, in: Science 313, Nr. 5788, 11.08.2006, 803-807: http://www.unikoeln.de/inter-fak/sfb389/sonstiges/kroepelin/242\%202006\%20Kuper\%20Kroepelin\% 20Science\%20313\%20\%20(11\%20August\%202006).pdf.

Kuper, R., Archaeology of the Gilf Kebir National Park: http://www.uni-koeln.de/hbi/Texte/Gilf_ Kebir.pdf.

Le Lay, C., Le zodiaque de Denderah, in: CLEA Cahiers Clairaut,2001 : http://clea-astro.eu/archi ves/cahiers-clairaut/CLEA_CahiersClairaut_094_08.pdf.

The Librarians. The Blog of the National Library of Israel, Begin discovers Egypt: https://blog. nli.org.il/en/begin-discovers-egypt.

Manning, S. et al., Integrated Tree-Ring-Radiocarbon High-Resolution Timeframe to Resolve Earlier Second Millennium BCE Mesopotamian Chronology, in: PLoS ONE 11.7, 2016: https://journals.plos.org/plosone/article/file?id=10.1371/journal. pone. $0157144 \&$ type= printable.

Maul, S. M., Wer baute die babylonische Arche? Ein neues Fragment der mesopotamischen Sintfluterzählung aus Assur, 2008: https://www.uni-heidelberg.de/fakultaeten/philoso phie/ori/assyriologie/forschung/gilga.html.

McGill Universtiy Archives, Montreal, Fonds MG 4248 - Charles Alexander Brodie-Brockwell Fonds, CA MUA MG 4248: https://archivalcollections.library.mcgill.ca/index.php/charlesalexander-brodie-brockwell-fonds.

McNairn, B., Method and theory of V. Gordon Childe, Diss., Edinburgh 1978: https://era.ed.ac. uk/handle/1842/18438.

Millerman, A. J., The Spinning of Ur. How Sir Leonard Woolley, James R. Ogden and the British Museum interpreted and represented the past to generate funding for the excavation of Ur in the 1920s and 1930s, Diss., Manchester 2015: https://www.research.manchester.ac. uk/portal/files/54575218/FULL_TEXT.PDF.

Montet, P., Le Temple Pharaonique et la Querelle des Égyptologues, in: Le Monde, 18. 07.1951: https://www.lemonde.fr/archives/article/1951/07/18/le-temple-pharaonique-et-la-querel le-des-egyptologues_2075105_1819218.html.

Morenz, L., Ereignis Reichseinigung und der Fall Buto. Inszenierungen von Deutungshoheit der Sieger und - verlorene - Perspektiven der Verlierer, in: IBAES X: Fitzenreiter, M. (Hg.), Das Ereignis - Geschichtsschreibung zwischen Vorfall und Befund, Berlin 2009, 199-209: https://www.ibaes.de/ibaes10/publikation/morenz_ibaes10.pdf.

Müller-Römer, F., Richard Lepsius - Begründer der modernen Ägyptologie, 2009: http://archiv. ub.uni-heidelberg.de/propylaeumdok/volltexte/2009/460.

Newton, I., A Dissertation upon the Sacred Cubit of the Jews and the Cubits of the several Nations, übers. v. J. Greaves, in: Miscellaneous Works of Mr. John Greaves, Professor of Astronomy in the University of Oxford, Bd. 2, London 1737, 405-433: The Newton Project: http://www.newtonproject.ox.ac.uk/view/texts/normalized/THEM00276.

Parco Archeologico dei Campi Flegrei, Macellum/Tempio di Serapide: http://www.pafleg.it/it/ 4388/localit/67/macellum-tempio-di-serapide.

Projektbeschreibung CHRONOI: https://www.ec-chronoi.de/exploration/zeitgeist. 
Raffaele, F., On the terms „Dynasty 0“ and „Dynasty 00“, 2003: http://xoomer.virgilio.it/fran cescoraf/hesyra/dynasty.htm.

Saur, M., S.v. „Berossos“, in: WiBiLex. Das wissenschaftliche Bibellexikon im Internet, 2009: https://www.bibelwissenschaft.de/stichwort/14996.

Stevenson, A., ,We Seem to be Working in the Same Line': A. H. L. F. Pitt-Rivers and W. M. F. Petrie, in: Bulletin of the History of Archaeology 22.1, 2012, 4-13: https://www.archaeo logybulletin.org/articles/10.5334/bha.22112.

The Times, 27.03.2006: „Germans are brainiest (but at least we're smarter than the French)“: https://www.thetimes.co.uk/article/germans-are-brainiest-but-at-least-were-smarter-thanthe-french-w86q5665ws3.

Tietze, C. / Maksoud, M. / Lange, E., Ein Schaltjahr für das Königspaar, in: Portal. Die Potsdamer Universitätszeitung 4/5, 2004: https://www.uni-potsdam.de/fileadmin/pro jects/up-entdecken/docs/portal/Archiv/2004/2.pdf.

Tischendorf, Lobegott Friedrich Constantin von, in: Kotte Autographs: https://www.kotte-auto graphs.com/de/autograph/tischendorf-lobegott-friedrich-constantin-von.

Warburton, D. A., Egyptian History: Definitely! Myth as the Link between Event and History, in: IBAES X: Fitzenreiter, M. (Hg.), Das Ereignis - Geschichtsschreibung zwischen Vorfall und Befund, Berlin 2009, 283-307: https://www.ibaes.de/ibaes10/publikation/warburton_ ibaes10.pdf.

\section{Abbildungsnachweis}

Abb. 1a+b: Vom Autor selbst erstellt.

Abb. 2: $\quad$ Bayerische Staatsbibliothek, München: Bildnr. 5-17. 01. 2018 01:55; 7-17. 01. 2018 01:55.

Abb. 3: $\quad$ Bayerische Staatsbibliothek, München: Bildnr. 1-16.11. 2019 06:26.

Abb. 4: Jomard, E. F. (Hg.), Description de l'Égypte, ou recueil des observations et des recherches qui ont été faites en Égypte pendant l'expédition de l'armée française, publié par les ordres de Sa Majesté l'Empereur Napoléon le Grand, Bd. 2, 2, 4: Planches 4, Taf. 21 - Universitätsbibliothek Heidelberg, Sig. A 5574.

Abb. 5: $\quad$ Bayerische Staatsbibliothek, München: Bildnr. 1-13.03.2018 20:08.

Abb. 6: Bayerische Staatsbibliothek, München: Bildnr. 733-06.02.2020 02:01.

Abb. 7: Gemeinfrei: https://commons.wikimedia.org/wiki/File:Joseph_Gathering_Corn_ (San_Marco).jpg.

Abb. 8: $\quad$ Petrie, W. M. Flinders / Mace, A. C., Diospolis Parva, the cemeteries of Abadiyeh and Hu, London 1901, Frontispiz. - Courtesy of The Egypt Exploration Society.

Abb. 9a+b: Courtesy of The Petrie Museum of Egyptian Archaeology, UCL.

Abb. 10: Neugebauer, O. / Parker, R. A. (Hg.), Egyptian Astronomical Texts, Bd. 3: Decans, Planets, Constellations and Zodiacs, London 1969, Taf. 18.

Abb. 11: Woolley, L., Ur Excavations 4: The early Periods, Philadelphia 1955, Taf. 72 - Universitätsbibliothek Heidelberg, Sig. C 3047-21.

Abb. 12: Vom Autor selbst erstellt auf Grundlage von: Sethe, K., Urgeschichte und älteste Religion der Ägypter (Abhandlungen für die Kunde des Morgenlandes 18.4), Leipzig 1930, Karten 1-3. 
Abb. 13: Elliot Smith, G., The Migrations of Early Culture. A Study of the Significance of the Geographical Distribution of the Practice of Mummification as Evidence of the Migrations of Peoples and the Spread of certain Customs and Beliefs, London 1915, S. 14.

Abb. 14: Almásy, L. E., Unbekannte Sahara. Mit Flugzeug und Auto in der Libyschen Wüste, Leipzig 1939, zwischen S. 136 und 137.

Abb. 15: Gemeinfrei: Wikimedia Commons: https://commons.wikimedia.org/wiki/File:Willi am_Albright_1957.jpg.

Abb. 16: Breasted, J. H., Ancient Times, a History of the Early World. An Introduction to the Study of Ancient History and the Career of Early Man, Boston 1916, S. 100-101. 